\title{
Akdağ’ın (Balıkesir-Kütahya) bitki çeşitliliği ile çevresel faktörler arasındaki ilişkiler ve bitki toplumlarının tür çeşitliliği
}

Species diversity of plant communities and relationships between environmental factors and plant diversity of Akdağ (Balıkesir-Kütahya)

\author{
Münevver ARSLAN ${ }^{1}$ \\ Nejat CELİK ${ }^{1}$ \\ Cezmi ÖZEL1 \\ Ali TÖRÜ 1 \\ Kürşad ÖZKAN²
} ${ }^{1}$ Orman Toprak ve Ekoloji Araştırmaları
Enstitüsü Müdürlüğü, Eskişehir
${ }^{2}$ Isparta Uygulamalı Bilimler Üniversitesi,
Orman Fakültesi, Isparta

Sorumlu yazar (Corresponding author) Münevver ARSLAN

munevverarslan@ogm.gov.tr

Geliş tarihi (Received)

11.10.2021

Kabul Tarihi (Accepted)

22.12.2021

Sorumlu editör (Corresponding editor) Şükrü Teoman GÜNER

stguner@gmail.com

Atıf (To cite this article): Arslan, M. , Celik, N. Özel, C. , Törü, A. \& Özkan, K. (2022). Akdağ' ’n (Balıkesir-Kütahya) bitki çeşitliliği ile çevresel faktörler arasındaki ilişkiler ve bitki toplumlarının tür çeșitliliği . Ormancılık Araștırma Dergis , 9 (2) , 108-121 . DOI: 10.17568/ogmoad.1005603

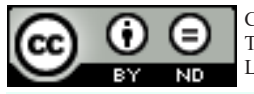

Creative Commons Atıf Tiretile 4.0 Türetilemez 4.0 Uluslararas
Lisansı ile lisanslanmıștır.
Öz

$\mathrm{Bu}$ çalışma, farklı floristik bölgelerin bitki toplumlarına sahip Akdağ'ın hem bitki toplumlarındaki bitki tür çeşitliliğini hem de bitki tür çeşitliliği ile çevresel faktörler arasındaki ilişkileri belirlemek amacıyla gerçekleştirilmiştir. Örnek alanlardaki bitki türlerinin örtüş-bolluk değerleri Braun-Blanquet skalasına göre belirlenmiştir. Orman ve çalı vejetasyonunu oluşturan bitki toplumları, kümeleme analiziyle gruplandırılmıştır. Tür çeşitlilik bileşenleri (alfa, beta ve gama çeşitlilikleri) bilgi teorisi ölçümleri kullanılarak hesaplanmıştır. Örnek alanların alfa çeşitliliği üzerinde etkili olan çevresel değişkenler, korelasyon analizi kullanılarak belirlenmiştir. En yüksek alfa, beta ve gama çeşitliliği Cistus laurifolius-Pinus nigra subsp. pallasiana, Aristolachia pallida-Quercus cerris, Astragalus glycyphyllos subsp. glycyphylloides-Pinus nigra subsp. pallasiana bitki gruplarında bulunmuştur. Tür çeşitliliği üzerinde en önemli çevresel faktörler ağaç katı örtme oranı ve yükseltidir. Alfa çeşitliliği ile ağaç katı örtme oranı ve yükselti arasında negatif, $\mathrm{pH}$ ile pozitif ilişki bulunmuştur. Örnek alanların alfa çeşitliliği ile çevresel faktörler arasındaki ilişkilerin modellenmesinde, en yüksek varyansı açıklama oranı $(\% 48,7)$ aşamalı çoklu regresyon analizinde elde edilmiştir. Ağaç katı örtme oranının azaldığı, alan heterojenliğinin ve karışık ağaç türlerinden oluşan bitki toplumlarının bulunduğu alanların bitki tür çeşitliliğini artırdığı ifade edilebilir.

Anahtar kelimeler: Alfa-Beta-Gama çeşitliliği, Orman ve çalı vejetasyonu, Yetişme ortamı faktörleri

\section{Abstract}

This study was carried out in order to determine both the plant species diversity in the plant communities of Akdağ, which includes the plant communities of different floristic regions, and the relationships between plant species diversity and environmental factors. The cover-abundance values of plant species in the sample areas were determined according to the Braun-Blanquet scale. Plant communities of forest and shrub vegetation were grouped by using cluster analysis. The components of species diversity (alpha, beta and gamma diversities) were defined by using information theoretic measures. Environmental variables affecting the alpha diversity of the sample areas were determined by correlation analysis. The highest alpha, beta and gamma diversities were found in Cistus laurifolius-Pinus nigra subsp. pallasiana, Aristolachia pallida-Quercus cerris, Astragalus glycyphyllos subsp. glycyphylloides-Pinus nigra subsp. pallasiana groups. The most important environmental factors on species diversity are tree layer cover and elevation. There was a negative relationship between alpha diversity and tree layer cover and elevation, and a positive relationship with $\mathrm{pH}$. In modeling the relationships between alpha diversity of the sample areas and environmental factors, the model with the highest proportion of variance explained (48.7\%) was obtained in the stepwise multiple regression analysis. It can be said that the areas with reduced tree layer coverage, area heterogeneity and plant communities consisting of mixed tree species increase plant species diversity.

Keywords: Alpha-Beta-Gamma diversity, Forest and shrub vegetation, Site factors 


\section{Giriş}

Türkiye'nin üç tarafının denizlerle çevrili olması, batıdan doğuya doğru artan yükseltisi, zengin topoğrafik yapısı ve bunların bir sonucu olarak çok farklı habitatları, vejetasyonun ve bitki türünün zenginliğinde etkili olmuştur (Avc1, 1996; Günal, 2013). Dolayısıyla Türkiye, büyük bir kıtanın sahip olabileceği derecede canlı türü çeşitliliğine de sahiptir (Işık, 2014). Ayrıca Türkiye üç büyük flora bölgesine ev sahipliği yapmaktadır.

Balıkesir ve Kütahya İlleri arasında konumlanan Akdağ üç flora bölgesinin kesişiminde yer alan dağlardan biridir. Balıkesir İli’nin en yüksek dağ1 olan Akdağ (2069 m)'ın coğrafi konumu ve yükselti farkı, değişik bitki toplumlarının oluşmasında etkili olmuştur (Sönmez ve Boyraz, 2003; Açar ve Satıl, 2014). Akdağ'ın florasında 442 takson belirlenmiştir (Açar ve Satıl, 2014). Bu sayı doğrudan tür zenginliği olarak ifade edilebilir. Ancak, bir ekosistemdeki "tür sayısının" kendi başına o ekosistemdeki biyolojik çeşitliliğin kesin bir ölçüsü olmadığı da bilinmelidir (Işık, 2014). Biyolojik çeşitlilik unsurlarından biri olan tür çeşitliliği, bulundukları ortamla süregelen ilişkilere bağlı olarak değişkenlik gösterir (Kılınç ve Kutbay, 2004; Işık, 2014). Bölgesel veya alansal ölçekte, topoğrafyadaki coğrafik değişkenlikler, güneşlenme, toprak özellikleri bitki tür çeşitliliğine güçlü bir şekilde etki eder (Urban ve ark., 2000; Poulos ve ark., 2007). Yapılan bir çok çalışmada bitki tür çeşitliliği üzerinde etkili olan çevresel faktörlerin farklı ekosistemler ve bölgelere göre değiştiği ortaya konulmuştur (Pausas ve Carreras,
1995; Gimaret-Carpentier ve ark., 1998; Gould ve Walker, 1999; Brewer ve ark., 2003; Gupta ve ark., 2008; Heydari ve Mahdavi, 2009; Chytrý ve ark., 2010; Negiz ve Aygül, 2019). Yetişme ortamına, vejetasyon tipine, bitki toplumlarına göre bitki tür çeşitliliği de değişmektedir. Dolayısıyla farklı ekosistemlerde tür çeşitliliğinin çalışılması ve tür çeşitliğini etkileyen çevresel faktörlerle ilişkilerin değerlendirilmesi gerekir (Arslan ve ark., 2019). Çalışmamıza konu olan Akdağ, Akdeniz flora bölgesinde yer almasına rağmen farklı flora bölgelerinin bitki toplumlarını bir arada bulundurur. Dolayısıyla bu bitki toplumlarının ekolojik istekleri de birbirinden farklıdır. Çalışmamızda Akadağ'ın orman ve çalı vejetasyonunun tür çeşitliliği, bitki tür çeşitliliği ile yetişme ortamı faktörleri arasındaki ilişkiler değerlendirilmiştir.

\section{Materyal ve Yöntem}

\section{1. Çalıșma alanı}

Ege Bölgesinin İç Batı Anadolu Bölümü’nde yer alan Akdağ 2069 m yüksekliğe sahiptir. KütahyaSimav İlçesi ile Balıkesir-Dursunbey İlçeleri arasında kalan çalışma alanı 4341490-4354485 kuzey enlemleri ile 644525-665507 doğu boylamları arasında yer almaktadır (Şekil 1).

Araştırma alanı, Davis'in enlem ve boylama dayalı grid sistemine göre $B_{2}$ karesinde (Davis, 1965) Akdeniz flora bölgesi sınırları içerisinde yer almasına rağmen İran-Turan ve Avrupa-Sibirya flora bölgelerinin kesişimine yakın bir alanda konumlanmıştır. Doğusunda Kütahya İli'nde yer alan Eğrigöz Dağı (2181 m) yer alır. Batısında, Balıkesir İli’nde

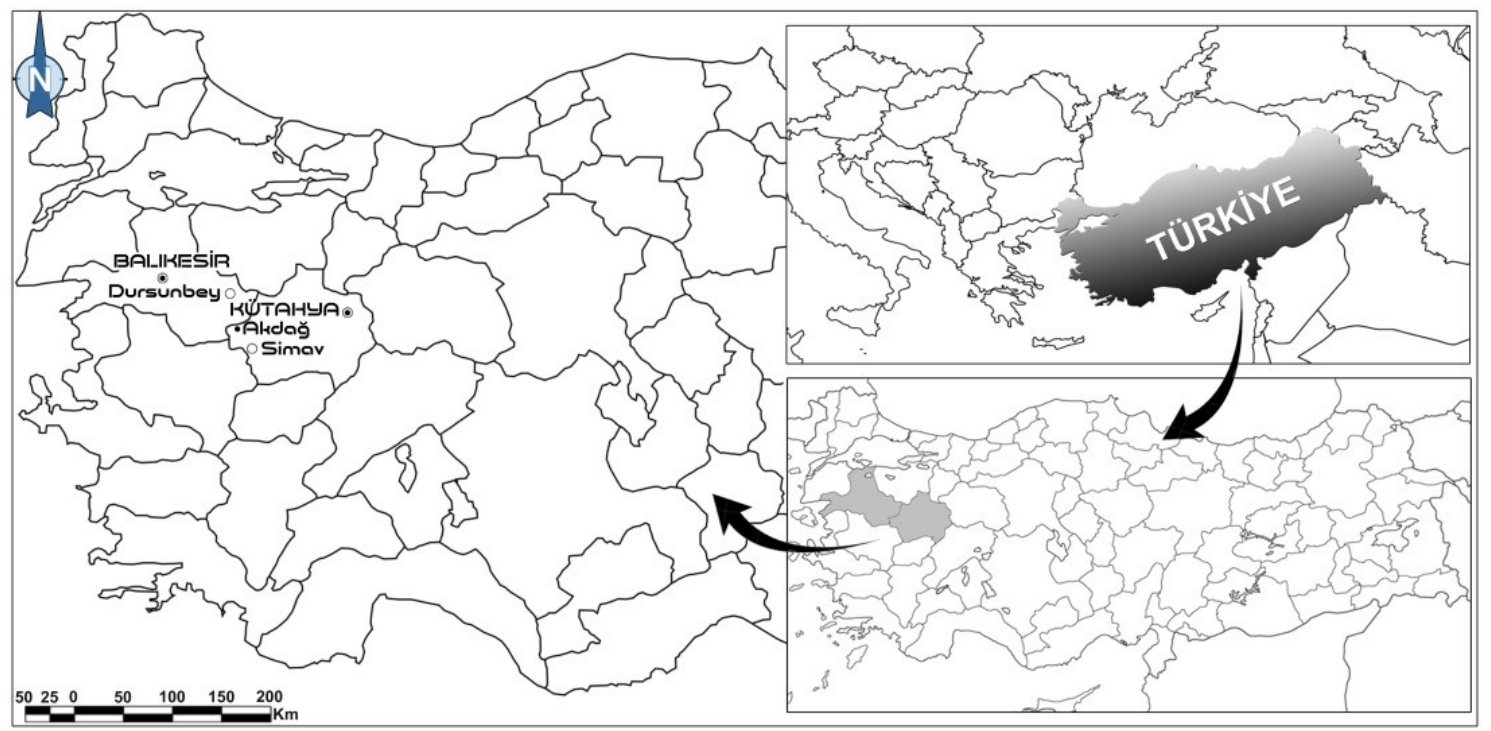

Şekil 1. Çalışma alanı haritası

Figure 1. Study area map 
yer alan Ulus Dağı (1.789 m), kuzeyinde ise Alaçam Dağları (1.615 m) vardır (Açar ve Satıl, 2014). Güneyinde Simav Ovası bulunmaktadır.

Akdağ'ın en yaygın orman toplumunu Anadolu karaçamı (Pinus nigra subsp. pallasiana) ve doğu kayını (Fagus orientalis) oluşturmaktadır. Daha aşağ 1 yükseltilerde genellikle sürgün kökenli Türk meşesi, saçlı meşe (Quercus cerris var. cerris) toplumu yayılış göstermektedir. Dağın zirvesinde ise Juniperus communis var. saxatilis klimaks çal1 vejetasyonu hậkimdir. Akdağ'da, yangınlardan sonraki ağaçlandırmalar ile dikilen Pinus brutia, Cedrus libani, Pinus sylvestris, Abies nordmanniana subsp. equitrojani, Robinia pseudoacacia gibi farklı ağaç türlerini de görmek mümkündür.

\section{2. Örnekleme ve veri toplama yöntemleri}

\subsubsection{Arazi çalışmaları}

Akdağ orman ve çalı vejetasyonunun optimum gelişme döneminde, vejetasyonu temsil edecek yerlerden 127 adet örnek alanda, Braun - Blanquet skalasina (Braun-Blanquet, 1932) göre $400 \mathrm{~m}^{2}$ lik alanda her bir bitki taksonuna ait bolluk-örtüş değerleri kaydedilmiştir. Çalışmanın arazi aşaması 2016-2018 yıllarında tamamlanmıştır. Fizyoğrafik faktörlerden bak1 $\left({ }^{\circ}\right)$ pusula ile eğim $\left({ }^{\circ}\right)$ ise eğimölçerle tespit edilmiştir. Örnek alanların yükselti (m) ve koordinatları Küresel Konumlama Sistemi (GPS, Global Positioning System), WGS 84 ile belirlenmiştir. Her örnek alanda açılan toprak çukurundan 0-10, 10-30 cm derinlik kademelerinden 1 litre hacminde toprak örnekleri alınmıştır. Arazi çalışmalarında anakayalar tam olarak tespit edilemediğinden Maden Tetkik ve Arama Genel Müdürlüğü'nden 1/25000'lik jeoloji haritası temin edilmiştir. Arazide tanısı yapılamayan bitki örnekleri herbaryum tekniklerine göre toplanıp kurutulmuştur (Yaltırık ve Efe, 1996)

\subsection{2. Çalışma alanının biyoiklimi}

Çalışma alanına en yakın Simav meteoroloji istasyonunun (809 m) 1960-2018, Dursunbey meteoroloji istasyonunun $(637 \mathrm{~m})$ 1966-2018 y1lları arasındaki iklim verileri değerlendirilmiştir. İklimsel yorumlamalar fotoperiyodizmi günlük ve mevsimlik olan tüm iklimler için geliştirilen Emberger metodu ile elde edilen sonuçlara göre yorumlanmıştır (Akman ve Daget, 1971; Akman, 1999). Ayrıca, çalışma alanının ortalama yükseltisi (1.400 m) için Dursunbey İstasyonu verilerinden sıcaklık her $100 \mathrm{~m}>$ de $0,5^{\circ} \mathrm{C}$ azaltılarak (Erinç, 1984), yağ 1 ş ise Schreiber formüllüne göre her $100 \mathrm{~m}>$ de $54 \mathrm{~mm}$ arttırılarak (Özyuvacı, 1999) hesaplanmıştır.

\subsection{Büro çalışmaları}

\subsubsection{Bitki örneklerinin teşhisi, fizyografik faktörler ve toprak analizleri}

Bitki türleri başlıca "Flora of Turkey and the East Aegean Islands" adlı eserden (Davis, 1965-1985; Davis ve ark., 1998; Güner ve ark., 2000) yararlanılarak teşhis edilmiştir. Bazı morfolojik özellikleri farklı olan bitki türlerinin teşhisinde Tutin ve Heywood, (2010) eserinden, 2000 yılından sonra yeni bulunan bitki taksonlarının tanısında ise çeşitli yayınlardan (Özbek, 2010; Özbek ve ark., 2011; Pimenov ve Kljuykov, 2010; Güner ve Duman, 2013; Tunçkol ve ark., 2015) faydalanılmıştır. Teşhislerde binoküler kullanılmıştır. Yamaç konumu Google Earth programında \% olarak belirlenmiştir. İstatistik analizlerde fizyografik faktörlerden bakılar, radyasyon indeksine (RI) dönüştürülerek sayısal analizlerde kullanılmıştır (Moisen ve Frescino, 2002; Aertsen ve ark., 2010).

$R I=\frac{[1-\cos ((\pi / 180)(Q-30))]}{2} R I:$ Radyasyon indisi; $Q$ : Örnek alanın kuzeye göre semt açısı

Jeoloji haritaları tarafımızdan sayısallaştırılarak elde edilen harita üzerinde örnek alanların yer aldığı noktalara ait anakayalar tespit edilmiştir.

Toprak örnekleri, hava kurusu hale geldikten sonra ögüüülüp 2 mm'lik elekten geçirilerek analize hazır hale getirilmiştir. Fiziksel toprak analizlerinden kum (\%), toz (\%) ve kil (\%) (tekstür) Kroetsch ve Wang (2008)'a göre, toprak türü İşletme İçi Metot (MT 06) ile kimyasal toprak analizlerinden toprak reaksiyonu (pH) TS ISO 10390 (TSE, 2013), organik madde miktarı (\%) Modifiye Walkley-Black yöntemi (TS 8336) (TSE, 1990), elektriksel iletkenlik (EC X 10-3 $\mathrm{mS} / \mathrm{cm}$ ) tayini TS ISO 11265 yöntemine (TSE, 1996a) göre 1:5 oranında toprak-su solüsyonunda, kireç $\left(\mathrm{CaCO}_{3} \%\right)$ Volumetrik Metot (TS 8335 ISO 10693) (TSE, 1996b) ile tayin edilmiştir.

\subsection{2. İstatistiksel değerlendirmeler}

\subsubsection{Vejetasyon analizi;}

Arazide kaydedilen vejetasyon tablosu verileri excel çalışma sayfasına kaydedildikten sonra TURBOVEG veri tabanına (Hennekens ve Schaminée, 2001) aktarılmıştır. TURBOVEG veri tabanına kaydedilen vejetasyon tablosu daha sonra JUICE (Tichý, 2002) paket programına aktarılmış ve PCORD (McCune ve Meffords, 2006)'da kümeleme analizi yapılmıştır. JUICE programı içerisinde grupların ayırımını hangi kesme seviyesinden ya- 
pacağımızı belirlemek amacıyla OPTIMClass analizi yapılmıştır. $\mathrm{Bu}$ analizde farklı mesafe ölçüsü ve grup bağlantı metotları ile analizler yenilenmiş ve en iyi kesme seviyesinin 5'li grup, en uygun mesafe ölçüsünün Relative Euclidean formülü ve grup bağlantısın ise Flexible Beta $(-0,25)$ metodu olduğu görülmüştür.

\subsubsection{2. Örnek alanların ve bitki gruplarının bitki tür çeşitliliği}

Bitki tür çeşitliliği indisleri hesaplanmadan önce her bir örnek alandaki bitki türlerinin BraunBlanquet bolluk-örtüş değerleri $0-1$ aralığındaki değerlere atanarak (r: $0.01 ;+: 0.02 ; 1: 0.04 ; 2: 0.15$; 3: $0.375 ; 4: 0.625 ; 5: 0.875)$ sayısallaştırılmıştır (Fontaine ve ark., 2007). Çalışma alanında tespit edilen her bir bitki toplumu, bitki türleri ve örnek alanlardan oluşan veri tablolarından oluşmaktadır. Bunun matematiksel ifadeler ile temsili gösterimi Tablo 1'de verilmiştir.

Tablo 1. Her bir toplum için hazırlanan veri matrislerinin gösterimi

Table 1. Representation of data matrices prepared for each plant community

\begin{tabular}{|c|c|c|c|c|c|c|}
\hline & & \multicolumn{4}{|c|}{ Örnek alanlar } & \multirow{2}{*}{$\frac{\sum}{P(y)}$} \\
\hline & & $K_{1}$ & $K_{2}$ & $\ldots$ & $K_{\mathrm{m}}$ & \\
\hline & $\mathrm{S}_{1}$ & $P_{11}$ & $P_{12}$ & $\ldots$ & $P_{1 \mathrm{k}}$ & $P+1$ \\
\hline Türler & $\mathrm{S}_{2}$ & $P_{21}$ & $\mathrm{P}_{22}$ & $\ldots$ & $P_{2 \mathrm{k}}$ & $P_{+2}$ \\
\hline \multirow{3}{*}{$\sum$} & $\cdots$ & $\cdots$ & $\cdots$ & $\cdots$ & $\cdots$ & $\cdots$ \\
\hline & $S_{\mathrm{n}}$ & $P_{\mathrm{s} 1}$ & $P_{\mathrm{s} 2}$ & $\cdots$ & $P_{\text {sk }}$ & $P+\mathrm{s}$ \\
\hline & $P(x)$ & $P_{1+}$ & $P_{2+}$ & $\ldots$ & $P_{k+}$ & 1.00 \\
\hline
\end{tabular}

( $S=$ türler; $K=$ örnek alanlar)

Toplumların alfa $(\alpha)$, beta $(\beta)$ ve gama $(\gamma)$ çeşitliliğinin hesabı için bilgi teorisinin eşitlikleri kullanılmıştır (Shannon, 1948; Chao ve ark., 2013; Özkan, 2016). Bu bağlamda her bir toplum için marjinal entropiler (Eşitlik 1 ve Eşitlik 2), bileşik entropi (Eşitlik 3), ortak bilgi (Eşitlik 4) ve şartlı entropiler (Eşitlik 5 ve Eşitlik 6) hesaplanmıştır.

$$
\begin{aligned}
& H(X)=\sum_{x \in X} p(x) \ln p(x) \\
& H(Y)=\sum_{y \epsilon Y} p(y) \ln p(y) \\
& H(X, Y)=\sum_{x \in X} \sum_{y \epsilon Y} p(x, y) \ln p(x, y) \\
& H(X \mid Y)=H(X, Y)-H(Y) \\
& =\sum_{y \epsilon Y} p(y) H(X \mid Y=y) \\
& H(Y \mid X)=H(X, Y)-H(X) \\
& =\sum_{x \in X} p(x) H(Y \mid X=x) \\
& I(X ; Y)=H(X)-H(X \mid Y) \\
& =\sum_{x \in X} \sum_{y \epsilon Y} p(x, y) \ln \frac{p(x, y)}{p(x) p(y)}
\end{aligned}
$$

Veri matrisi gösterim tablosunda (Tablo 1) $P_{s k}$ türlerin oransal değerleridir ve formüllerde (Eşitlik 1-7) $p(x, y)$ olarak ifade edilmektedir. $P_{+s}$ ve $P_{\mathrm{k}+}$ örnek alanların ve türlerin oransal değerlerini temsil etmekte olup, formüllerde s1rası ile $p(y)$ ve $p(x)$ 'e karşılık gelmektedir. $\mathrm{Bu}$ durumda $\quad p_{1+}+p_{2+}+\cdots+p_{k+}=\sum_{x \in X} p(x)=1 \quad$ ve $p_{+1}+p_{+2}+\cdots+p_{+s}=\sum_{y \in Y} p(y)=1$ olmaktadir.

Tablo 1'deki düzene göre, Özkan (2016) tarafından açıklandığı üzere $H(Y \mid X)$ alfa çeşitliliği $(\alpha), H(Y)$ gama çeşitliliği $(\gamma)$ ve $I(X ; Y)$ beta çeşitliliği $(\beta)$ olarak ifade edilebilir. $I(X ; Y)$ eşit sayıda örnek alan içeren toplumların hesabında doğrudan kullanılabilir. Ancak bu çalışmada çeşitlilik hesaplamasına konu olan toplumları ifade eden örneklem sayısı farklıdır. Bu yüzden çalışmada, farklı örneklem sayısı ile temsil edilen toplumların karşılaştırılması için Chao ve ark. (2013) tarafından önerilen $\operatorname{nor}(I(X ; Y))$ eşitliği (eşitlik 7) kullanılarak bitki toplumlarının tür çeşitliliğine ait indis değerleri de ayrıca hesaplanmıştır.

$\operatorname{nor}(I(X ; Y))=\frac{I(X ; Y)}{\ln K}$

Eşitlikte $\boldsymbol{K}$ örnek alan sayısını ifade etmektedir.

\section{-Alfa çeşitlilik indisi ile çevresel faktörler arasındaki ilişkiler}

Bahsi geçtiği üzere $H(Y \mid X)$ alfa çeşitliliği $(\alpha)$ olup, her bir örnek alanın çeşitlik değerini vermektedir. Vejetasyon gruplarından bağımsız olarak örnek alanın $\alpha$ değerleri ile çevresel faktörler arasındaki ilişkiler istatistiksel olarak incelenmiştir. Şöyle ki, $\alpha$ indisi ile çevresel faktörler arasındaki ilișkilerin belirlenmesi amaciyla SPSS istatistik programında (Versiyon 21) korelasyon analizleri yapılmıştır. $\alpha$ ile anakayaların var/yok verileri arasındaki ilişkiler Spearman, diğer çevresel değişkenlerin sayısal verilerine (yükselti, eğim, yamaç konumu, ağaç katı genel örtme oranı (AGO), çalı katı genel örtme oranı (ÇGO, tekstür, oraganik madde (OM), kireç, $\mathrm{pH})$ ise Pearson korelasyon analizi uygulanmıştır. $\alpha$ indisi ile çevresel faktörler arasındaki ilişkiler ve ilişkilerin modellenmesinde çalı vejetasyonunda ağaç katı olmaması nedeniyle (AGO) dậhil edilmeden analizler yapılmıştır. Ayrıca sadece orman vejetasyonu örnek alanlara ait veriler ile AGO de dậhil edilerek istatistiksel analizler gerçekleştirilmiştir.

\section{-Tür çeşitliliğini etkileyen faktörlerin modellenmesi;}

Örnek alanların $\alpha$ çeşitliliği ile (bağımlı değişken- 
ler) yetişme ortamı özelliklerinin (bağımsız değişkenler) modellenmesinde aşamalı çoklu regresyon analizi (Özdamar, 2009) ve regresyon ağacı yöntemi (McKenney ve Pedlar, 2003; Özkan, 2012) ile hesaplanmıştır. Regresyon ağacı analizinde DTREG yazılımı (www.dtreg.com), aşamalı çoklu regresyon analizinde ise SPSS istatistik programı kullanılmıştır. $\mathrm{Bu}$ analizler, çalı vejetasyonunda ağaç katı olmadığ 1 için her iki vejetasyon tipi (orman ve çal $\left.1=\alpha_{T}\right)$ ve sadece orman vejetasyonu $\left(\alpha_{F}\right.$ için ayrı ayrı gerçekleştirilmiştir.

\section{Bulgular}

\subsection{Biyoiklim, flora ve vejetasyon analizi}

Simav istasyonunun biyoiklimi, az yağışlı kışı soğuk Akdeniz, Dursunbey istasyonunun ise yar1-kurak kışı soğuk Akdeniz biyoiklim tipindedir. Çalışma alanının ortalama yükseltisi (1400) m için yükseltisi için enterpole edilen iklim verilerine göre, yıllık yağış toplamı $915,3 \mathrm{~mm}$, yıllık ortalama sıcaklık $8,5^{\circ} \mathrm{C}$ 'dir. Bu yükseltide yağışı1-az yağışlı arasında değişim gösteren kışı çok soğuk Akdeniz biyoiklim tipi görülür (Tablo 2).

Tablo 2. Simav ve Dursunbey meteoroloji istasyonlarının biyoiklimi

Table 2. Bioclimate of Simav and Dursunbey meteorological stations

\begin{tabular}{|c|c|c|c|c|c|c|c|c|c|}
\hline \multicolumn{2}{|c|}{ İstasyonun } & \multirow{2}{*}{$\mathrm{P}$} & \multirow{2}{*}{ M } & \multirow{2}{*}{$\mathrm{m}$} & \multirow{2}{*}{$\mathrm{PE}$} & \multirow{2}{*}{ Q } & \multirow{2}{*}{$\mathrm{S}$} & \multirow{2}{*}{$\begin{array}{l}\text { Yağ1ş } \\
\text { rejimi }\end{array}$} & \multirow{2}{*}{ Biyoiklim tipi } \\
\hline Ad1 & $\mathrm{Y}(\mathrm{m})$ & & & & & & & & \\
\hline Simav & 809 & 773,6 & 29,8 & $-1,4$ & 53,4 & 86,3 & 1,79 & KİSY & Az yağ1şlı k1şı soğuk Akdeniz biyoikilimi \\
\hline Dursunbey & 637 & 537,4 & 29,7 & $-0,8$ & 54,8 & 61,3 & 1,84 & KİSY & Yarıkurak k1şı soğuk Akdeniz biyoiklimi \\
\hline $\begin{array}{l}\text { Dursunbey } \\
\text { enterpole }\end{array}$ & 1400 & 915,3 & 25,9 & $-4,6$ & 91,3 & 105,7 & 3,53 & KİSY & $\begin{array}{l}\text { Yağışl1-az yağışlı k1ş1 çok soğuk Akdeniz } \\
\text { biyoiklimi }\end{array}$ \\
\hline
\end{tabular}
mum temperature of the hottest month) $\left({ }^{\circ} \mathrm{C}\right) ; \mathrm{m}$ : En soğuk ayın minimum sicaklık ortalaması (minimum average temperature of the coldest month) $\left({ }^{\circ} \mathrm{C}\right)$; PE: Yaz yağışı toplamı (summer precipitation total) (mm); S: kuraklık indisi (drought index)= PE/M; Q: Yağış-sıcaklık emsali (precipitation-temperature equality)

Çalışmamız sonucunda, Akdağ orman ve çalı vejetasyonunda 359 adet damarlı (vasküler) bitki taksonu bulunmuştur. Bu taksonların 45 adedi endemiktir (endemizm oranı \%12,5). Orman ve çalı vejetasyonunda 70 adet taksonla en fazla AvrupaSibirya flora bölgesi elementleri yer alır (Tablo 3).

Tablo 3. Orman ve çalı vejetasyonunda bulunan bitki taksonlarının fitocoğrafik bölgeleri

Table 3. Phytogeographic regions of plant taxa found in forest and shrub vegetation

\begin{tabular}{lc}
\hline Flora bölgeleri & Takson sayıs1 \\
\hline Avrupa-Sibirya & 70 \\
Akdeniz & 53 \\
İran-Turan & 7 \\
Hirkanya-Öksin & 1 \\
Bölgesi belirsiz & 228 \\
TOPLAM & 359 \\
\hline
\end{tabular}

Örnek alan verilerine uygulanan kümeleme analiziyle Akdağ'ın orman ve çalı vejetasyonu 5 bitki toplumuna ayrılmıştır (Şekil 2);

1. Grup: Cistus laurifolius-Pinus nigra subsp. pallasiana (24 örnek alan),

2. Grup: Aristolachia pallida-Quercus cerris (5 örnek alan),

3. Grup: Astragalus glycyphyllos subsp. glycyphylloides-Pinus nigra subsp. pallasiana (76 örnek alan),
4. Grup: Helictotrichon pubescens subsp. pubescens-Juniperus communis var. saxatilis (4 örnek alan)

5. Grup: Pinus nigra subsp. pallasiana-Fagus orientalis (18 örnek alan).

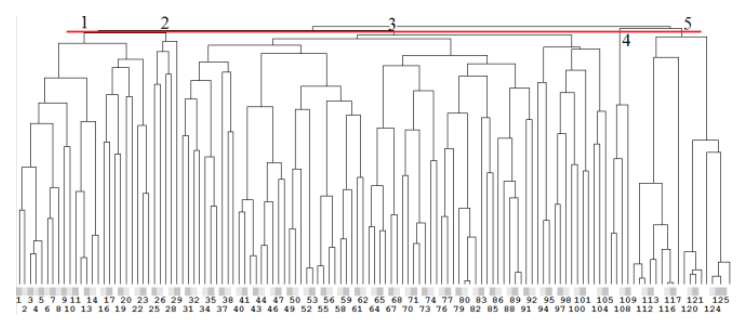

Şekil 2. Bitki gruplarına ait kümeleme analizi Figure 2. Cluster analysis of plant groups

\subsection{Bitki gruplarının ve örnek alanların tür çeşitliliği}

Bitki gruplarının ve örnek alanların tür çeşitliliği EK-1'de verilmiştir. Bitki gruplarının tür çeşitliği indis değerlerinden $\alpha$ (alfa), $\beta$ (beta) ve gama $(\gamma) 2$. Grupta en yüksek bulunmuştur (Şekil 3).

\subsection{Tür çeşitliliği ile çevresel faktörler arasındaki ilişkiler}

Çevresel faktörlerle (EK-2) $\alpha$ indisi değerlerine uygulanan Pearson korelasyon analize göre tür çeşitliliği üzerinde en fazla etkili olan bağımsız değişkenler AGO ve yükseltidir (Tablo 4). Çalı ve- 
jetasyonunda ağaç katı bulunmadığından sadece orman vejetasyonuna ait örnek alanların çevresel faktörlerle olan ilişkileri ayrıca değerlendirilmiş ve benzer ilişkiler bulunmuştur (Tablo 4). Akdağ'da yer alan anakaya çeşitleri ile $\alpha$ değerleri arasında herhangi bir ilişki bulunamamıştır.

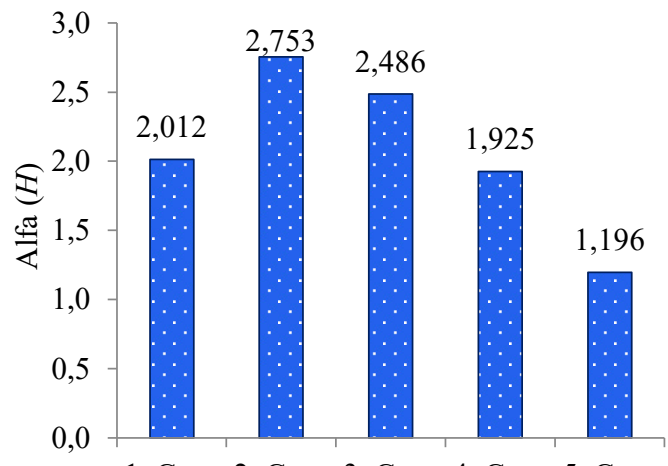

1. Grup 2. Grup 3. Grup 4. Grup 5. Grup

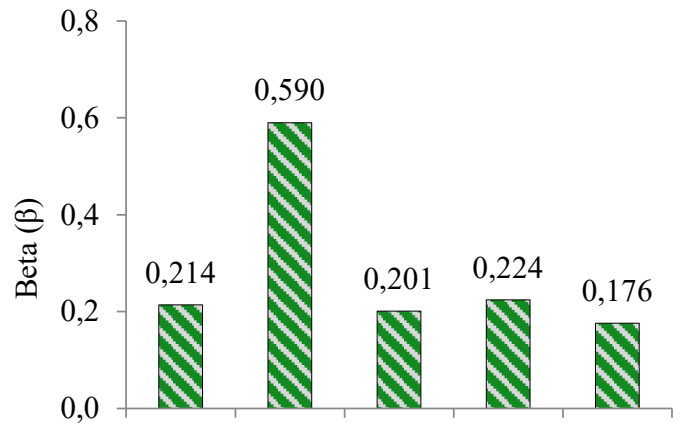

1. Grup 2. Grup 3. Grup 4. Grup 5. Grup

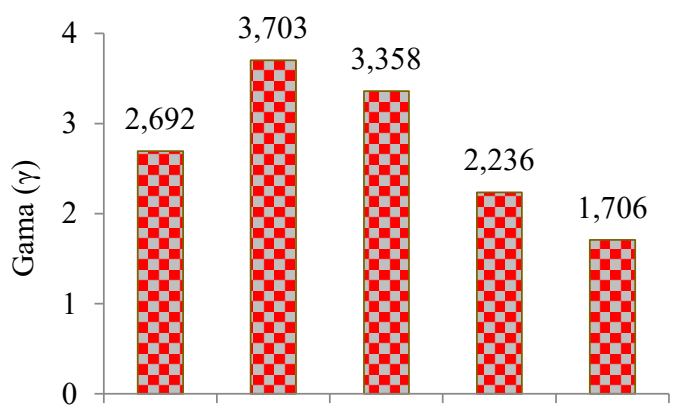

1. Grup 2. Grup 3. Grup 4. Grup 5. Grup

Şekil 3. Bitki gruplarının çeşitlilik bileşenleri $(H, \beta, \gamma)$ Figure 3. Diversity components of plant groups $(H, \beta, \gamma)$

\subsection{Tür çeşitliliğini etkileyen faktörlerin modellenmesi}

\section{-Aşamalı çoklu regresyon analizi}

Örnek alanların $\alpha$ değerleri ile çevresel faktörler arasındaki ilişkilere ait modellerin oluşturulabilmesi için yapılan aşamalı çoklu regresyon analizi sonucunda $\alpha$ indisi için en yüksek açıklama payına sahip model, 6. modeldir (Tablo 5).
Tablo 4. $\alpha$ indisi ile çevresel değişkenlere uygulanan Pearson korelasyon analizi

Table 4. Pearson correlation analysis applied to $\alpha$ index and environmental variables

\begin{tabular}{|c|c|c|c|c|}
\hline \multirow{2}{*}{$\begin{array}{c}\text { Çevresel } \\
\text { değişkenler }\end{array}$} & \multicolumn{2}{|c|}{ Tüm örnek alanlar } & \multicolumn{2}{|c|}{$\begin{array}{c}\text { Sadece orman } \\
\text { vejetasyonu }\end{array}$} \\
\hline & KKs & $\mathrm{P}$ & $\mathrm{KKs}$ & $\mathrm{P}$ \\
\hline Kum 1 & $-0,028$ & 0,757 & $-0,036$ & 0,694 \\
\hline $\mathrm{Kum}^{-} 2$ & $-0,033$ & 0,713 & 0,037 & 0,687 \\
\hline Toz $\overline{1}$ & $-0,152$ & 0,089 & $-0,147$ & 0,104 \\
\hline Toz_2 & $-0,086$ & 0,336 & $-0,085$ & 0,349 \\
\hline Kil-1 & $0,195^{*}$ & 0,028 & $0,207^{*}$ & 0,022 \\
\hline Kil 2 & 0,159 & 0,074 & 0,167 & 0,065 \\
\hline OM_1 & 0,050 & 0,578 & 0,051 & 0,576 \\
\hline $\mathrm{OM}^{-} 2$ & 0,010 & 0,907 & 0,038 & 0,673 \\
\hline Kirec_1 & $-0,167$ & 0,061 & $-0,159$ & 0,079 \\
\hline Kireç_2 & 0,013 & 0,884 & 0,014 & 0,876 \\
\hline pH $1^{-}$ & $0,230 * *$ & 0,009 & $0,230^{*}$ & 0,011 \\
\hline $\mathrm{pH}_{-}^{-} 2$ & $0,262 * *$ & 0,003 & $0,263 * *$ & 0,003 \\
\hline $\mathrm{EC}_{-}^{-1}$ & $-0,021$ & 0,815 & $-0,032$ & 0,723 \\
\hline $\mathrm{EC}^{-} 2$ & $-0,011$ & 0,898 & $-0,020$ & 0,828 \\
\hline $\mathrm{AGO}$ & $-0,356^{* * *}$ & 0,000 & $-0,542 * * *$ & 0,000 \\
\hline ÇGO & $-0,031$ & 0,728 & 0,001 & 0,990 \\
\hline Yükselti & $-0,302^{* *}$ & 0,001 & $-0,315^{* * *}$ & 0,000 \\
\hline RI & $-0,034$ & 0,705 & $-0,030$ & 0,745 \\
\hline Eğim & $-0,112$ & 0,212 & $-0,126$ & 0,164 \\
\hline YK & 0,020 & 0,827 & 0,015 & 0,866 \\
\hline
\end{tabular}

Çevresel değişkenlerden AGO çıkarılarak çalı ve orman vejetasyonuna giren örnek alanlarının tür çeşitliliği indis değerleri ile çevresel faktörler arasında gerçekleştirilen aşamalı çoklu regresyon analizinde modelinin açıklama payı $\left(\mathrm{R}^{2}=0,181\right)$ oldukça düşük bulunmuştur.

Sadece orman vejetasyonuna dậhil olan örnek alanların $\alpha$ indisi değerleri ile çevresel faktörlerin aşamalı regresyon analizinin modeli açıklama payı $\% 48,7$ 'dir. Orman vejetasyonu ve orman ve çalı vejetasyondaki tüm örnek alanların $\alpha$ indisi değerleri ile çevresel verilere uygulanan aşamalı çoklu regresyon analizi sonuçları karşılaştırıldığında ilişki gösteren çevresel değişkenlerin sadece önem seviyesinde çok az değişiklik olduğu tespit edilmiştir. Ayrıca modeli açıklama payı da $(\% 48,7)$ aynı değerde çıkmıştır. Bu nedenle sonuçlara ait tablo burada sunulmamıştır.

\subsection{Regresyon ağacı analizi}

$\alpha$ indisi değerleri ile çevresel faktörler arasında gerçekleştirilen regresyon ağacı analizi sonucunda $\alpha$ indisinin tahmininde kullanılabilecek modeli açıklayan değişken, sadece AGO’dür (Şekil 4). AGO çıkarılarak yapılan regresyon ağacı analizi sonucunda ise model yükselti değişkeniyle açıklanmıştır (Şekil 5). Sadece orman vejetasyonuna ait verileri kullanılarak yapılan regresyon ağacı analizinde ise AGO modeli açılkayan tek değişken olarak bulunmuştur (Şekil 6). 


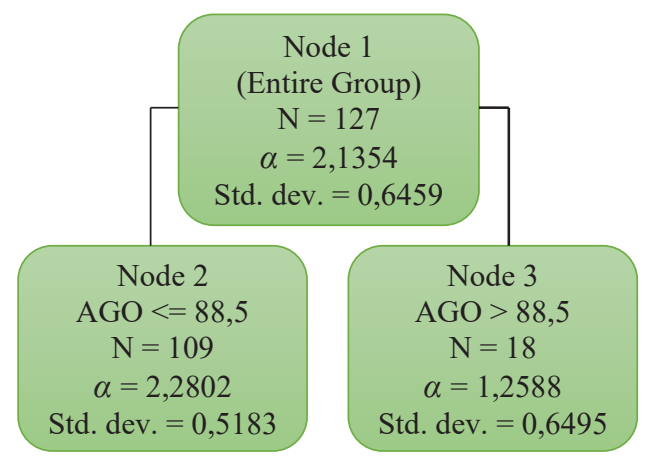

Şekil 4. $\alpha$ indisi tahmininde kullanılabilecek regresyon ağac1 modeli $\left(\mathrm{R}^{2}=\% 30,42\right)$ (Tüm örnek alanlar ve tüm çevresel veriler)

Figure 4. Regression tree model that can be used to estimate $\alpha$ index $\left(\mathrm{R}^{2}=30.42 \%\right)$ (All sample sites and all environmental data)

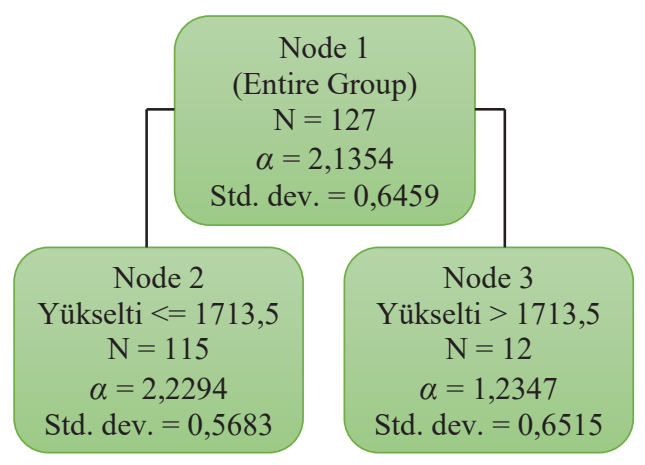

Şekil 5. Çevresel değişkenlerden AGO olmadan yapılan regresyon ağac1 modeli $\left(\mathrm{R}^{2}=\% 20,29\right)$

Figure 5. Regression tree model without AGO from environmental variables $\left(\mathrm{R}^{2}=20.29 \%\right)$

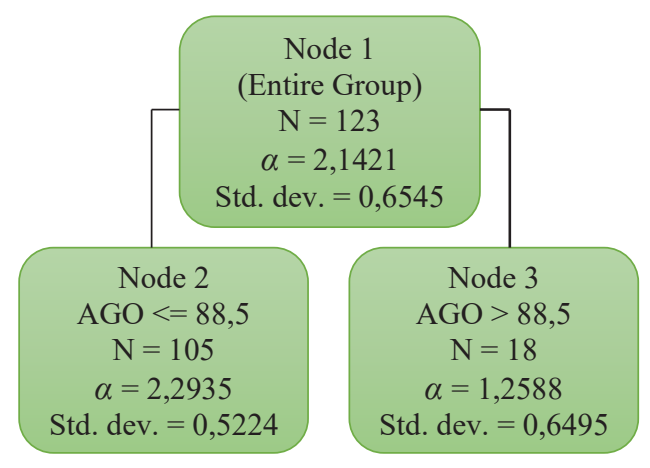

Şekil 6. Sadece orman vejetasyonuna ait verilere uygulanan regresyon ağac1 modeli $\left(\mathrm{R}^{2}=\% 20,29\right)$

Figure 6. Regression tree model applied only to forest vegetation data $\left(\mathrm{R}^{2}=20.29 \%\right)$

\section{Tartışma ve Sonuç}

Üç farklı flora bölgesinin kesişiminde yer alması ve yükselti farkının 1300 metreden fazla olmas1 sebebiyle Akdağ (Balıkesir ve Kütahya), farklı orman ve çalı vejetasyonunu bir arada bulundurmaktadır. Bu ekolojik farklılıklar orman ve çalı vejetasyonunu floristik açıdan zenginleştirmiş ve endemizm oranını \%12,5'e ulaştırmıştır. Nitekim Açar ve Satil (2014), Akdağ kütlesinde endemizm oranını \%10,41 olarak tespit etmişlerdir. Açar ve Satıl (2014) Akdağ'ın tamamında yaptıkları çalışmada, ilk sırada 87 taksonla Akdeniz, 76 taksonla Avrupa-Sibirya, İran-Turan flora bölgesi ise 35 taksonla temsil edilmektedir. Çalışmamızda ise tür zenginliği açısından orman ve çalı vejetasyonunda, Avrupa-Sibirya flora bölgesi elementleri 70 taksonla ilk sırada, ikici sırada ise 53 taksonla Akdeniz flora bölgesi elementleri yer almaktadır. Çalışma alanında yükseltinin artmasıyla birlikte yağışlı Akdeniz iklim tipinin (1.400 m'de) görülmesi, yar1kurak-kışı soğuk ve nemli-kışı çok soğuk iklim koşullarına adapte olan farklı bitki toplumlarının yetişmesine uygun ortamları oluşturduğu ifade edilebilir. Bu iklim koşullarında, kayın ormanları Akdağ'da geniş alanlarda saf ve karışık orman toplumları oluşturmuş ve bunun bir sonucu olarak en fazla takson sayısı Avrupa-Sibirya flora bölgesinde, ikinci sırada ise Akdeniz flora bölgesinde bulunmuştur. Her ne kadar çalışma sahası Akdeniz biyoiklim katında yer alsa da yağışlı ve nemli iklimi seven doğu kayınının alanda yayılış göstermesi Avrupa-Sibirya elementlerinin orman alanında daha fazla bulunmasında etkili olduğunu göstermektedir. Ayrıca Avrupa-Sibirya flora bölgesi takson sayısının diğer flora bölgelerine göre fazla olmasında, çalışma alanının bu flora bölgesine yakın bir yerde konumlanmasından da kaynaklanabilir.

Alfa çeşitlilik indisi ile çevresel faktörler arasında yapılan sayısal analizlere göre en önemli ilişki gösteren çevresel faktörler ağaç katı genel örtme oranı (AGO) ve yükseltidir. $\mathrm{Bu}$ değişkenleri $\mathrm{pH}$, toprağın ilk $10 \mathrm{~cm}$ 'sindeki kil miktarı takip etmektedir. $\alpha$ çeşitlilik indis değeri yükseltinin ve AGO'nün artmasıyla birlikte azalmakta, $\mathrm{pH}$ değeri yükseldikçe artmaktadır. Tür çeşitliliğinin en düşük olduğu örnek alanlar yüksek rakımlarda yer alan ve pH'nın düşük olduğu kayın-karaçam (Grup 5) ve sürünücü ardıç (Grup 4) toplumlarında yer almaktadır. Daha aşağı yükseltilerde karaçam ve saçlı meşe toplumları yer alır. Bu bitki toplumlarının $\alpha$ çeşitliliği daha yüksek çıkmasının nedeni kayın ormanına göre karşılaştırıldığında ağaç katı kapalılığının ve yükseltinin daha düşük, $\mathrm{pH}$ 'ın ise daha yüksek olmasıyla açıklanabilir.

Çalışmamızda yükseltinin artmasıyla birlikte tür çeşitliliği ve zenginliği azalmakta iken Pausas ve Sáez (2000) eğrelti tür zenginliğinin yükseltiyle dolayısıyla yağışın artmasıyla birlikte arttığını tespit etmişlerdir. Ağaç ve odunsu tür zenginliğinin 
Tablo 5. Tüm örnek alanların $\alpha$ indisi değerleri ile çevresel verilere uygulanan aşamalı çoklu regresyon analizi Table 5. Stepwise multiple regression analysis applied to environmental data with $\alpha$-index values of all sample areas

\begin{tabular}{|c|c|c|c|c|c|c|c|c|c|}
\hline Model & $\mathrm{R}^{2}$ & SE & $\mathrm{F}$ & $\begin{array}{c}\mathrm{p} \\
\text { (model) }\end{array}$ & Model değişkenleri & B & $\mathrm{t}$ & $\underset{\text { (değişken) }}{\mathrm{p}}$ & VIF \\
\hline \multirow{2}{*}{1} & \multirow{2}{*}{0,127} & \multirow{2}{*}{0,61} & \multirow{2}{*}{18,129} & \multirow{2}{*}{0,000} & Sabit değer & 3,006 & 14,211 & 0,000 & - \\
\hline & & & & & $\mathrm{AGO}$ & $-0,012$ & $-4,258$ & 0,000 & 1,000 \\
\hline \multirow{3}{*}{2} & \multirow{3}{*}{0,316} & \multirow{3}{*}{0,56} & \multirow{3}{*}{28,694} & \multirow{3}{*}{0,000} & Sabite değer & 3,819 & 16,359 & 0,000 & - \\
\hline & & & & & AGO & $-12,098$ & $-7,287$ & 0,000 & 1,486 \\
\hline & & & & & Andezit-Dasit & $-1,763$ & $-5,866$ & 0,000 & 1,486 \\
\hline \multirow{4}{*}{3} & \multirow{4}{*}{0,368} & \multirow{4}{*}{0,52} & \multirow{4}{*}{23,921} & \multirow{4}{*}{0,000} & Sabite değer & 4,301 & 15,845 & 0,000 & - \\
\hline & & & & & $\mathrm{AGO}$ & $-1,6218$ & $-8,176$ & 0,000 & 1,862 \\
\hline & & & & & Andezit-Dasit & $-0,008$ & $-5,523$ & 0,000 & 1,521 \\
\hline & & & & & ÇGO & 0,037 & $-3,185$ & 0,002 & 1,543 \\
\hline \multirow{5}{*}{4} & \multirow{5}{*}{0,422} & \multirow{5}{*}{0,5} & \multirow{5}{*}{22,229} & \multirow{5}{*}{0,000} & Sabite değer & 3,744 & 12,098 & 0,000 & - \\
\hline & & & & & $\mathrm{AGO}$ & $-0,028$ & $-8,552$ & 0,000 & 1,862 \\
\hline & & & & & Andezit-Dasit & $-1,732$ & $-6,099$ & 0,000 & 1,542 \\
\hline & & & & & ÇGO & $-0,009$ & $-3,544$ & 0,001 & 1,551 \\
\hline & & & & & Kil_1 & 0,030 & 3,347 & 0,001 & 1,035 \\
\hline \multirow{6}{*}{5} & \multirow{6}{*}{0,459} & \multirow{6}{*}{0,49} & \multirow{6}{*}{20,541} & \multirow{6}{*}{0,000} & Sabite değer & 4,450 & 11,501 & 0,000 & - \\
\hline & & & & & AGO & $-0,026$ & $-7,862$ & 0,000 & 1,975 \\
\hline & & & & & Andezit-Dasit & $-1,296$ & $-4,126$ & 0,000 & 2,001 \\
\hline & & & & & ÇGO & $-0,007$ & $-3,160$ & 0,002 & 1,589 \\
\hline & & & & & Kil_1 & 0,037 & 4,063 & 0,000 & 1,105 \\
\hline & & & & & Yükselti & $-0,001$ & $-2,898$ & 0,004 & 1,512 \\
\hline \multirow{7}{*}{6} & \multirow{7}{*}{0,487} & \multirow{7}{*}{0,48} & \multirow{7}{*}{18,959} & \multirow{7}{*}{0,000} & Sabite değer & 4,318 & 11,300 & 0,000 & - \\
\hline & & & & & $\mathrm{AGO}$ & $-0,027$ & $-8,303$ & 0,000 & 2,010 \\
\hline & & & & & Andezit-Dasit & $-1,359$ & $-4,408$ & 0,000 & 2,014 \\
\hline & & & & & ÇGO & $-0,008$ & $-3,255$ & 0,001 & 1,589 \\
\hline & & & & & Kil_1 & 0,039 & 4,391 & 0,000 & 1,117 \\
\hline & & & & & Yükselti & $-0,001$ & $-2,592$ & 0,011 & 1,540 \\
\hline & & & & & Çakıltaş1 & 0,303 & 2,537 & 0,012 & 1,063 \\
\hline
\end{tabular}

$\mathrm{R}^{2}$ : belirtme katsay1s1 (coefficient of determination); SE: tahmin edilen standart hata (std. error of the estimate); F: F-oran1 (F-ratio); p: önem seviyeleri (significance levels); B: standardize edilmemiş katsayı (Unstandatdized coefficient); T: T-değeri (T-value); VIF: Varyansı şişirme katsayısı (Variance inflation factor).

yükseltiyle birlikte artış gösterdiğini ortaya koyan çalışmalarda mevcuttur (Brewer ve ark., 2003 (ağaç tür zenginliği); Özkan, 2006 (odunsu tür zenginliği)). Ancak çalışmamızda sadece belirli yaşam formuna ait bitki türlerine odaklanılmamıştır. Çalışma alanındaki tüm vasküler bitki taksonları örneklenmiş, tür çeşitliliği indisleri hesaplanmış ve sayısal analizlere dậhil edilmiştir. Çalışmamız ve daha önce yapılan çalışmalar değerlendirildiğinde, tür çeşitliliği yetişme ortamının iklim koşullarına, bitki türlerinin hayat formuna (biyolojik spekturumu), hậkim vejetasyona ve jeomorfolojik yapıya göre değişkenlik gösterebilir.

Çalışma alanımızda üst yükseltilere çıkıldıkça yağışın arttığı görülmekte; ancak üst yükseltilerde tür çeşitliliği azalmaktadır. Burada tür çeşitliliğini etkileyen faktörün, yağıştan ziyade üst tabakayı oluşturan hậkim bitki türünün kapalılığı olduğu düşüncesini doğrulamaktadır.

Tür çeşitliliği ve zenginliği yüksek olan örnek alanlar ve bitki grupları daha aşağı rakımlarda (genellikle 1250-1550 m) yer almakta ve bu alanlarda ağaç katının kapalılığı düşük ve daha heterojendir. Alfa çeşitliliğinin en yüksek değerine $(3,601)$ sahip örnek alanın ağaç katı kapalılı̆̆ı (\%40), diğer örnek alanlara göre daha düşüktür. Bu örnek alan, aynı zamanda bitki tür zenginliğinin bir ölçütü olan en yüksek takson sayısını da içinde bulundurmaktadır. a çeşitliliğin yüksek olduğu diğer örnek alanlarda da aynı durum görülmektedir. Tür 
çeşitliliğinin yüksek olduğu örnek alanlarda ağaç katı kapalılı̆̆ 1 \%75'lere kadar çıkmaktadır. Aynı zamanda tür zenginliği ve çeşitliliğinin en yüksek olduğu örnek alanlar, tür çeşitliliği ve zenginliği yüksek olan bitki grupları içerisinde yer almaktadır. Alfa, beta ve gama çeşitliliği yüksek olan bitki grupları daha aşağı rakımlarda yer alırken tür çeşitliliği daha düşük bitki grupları (Grup 5 ve Grup 4) üst rakımlarda yer almaktadır. İran'daki Melah Gavan Koruma Alan'ında üst yükselti kuşaklarının tür çeşitliliği, 1400-1500 m'deki iklim kuşağından daha azdır (Heydari ve Mahdavi, 2009). Farklı bölgelerde yapılan bazı çalışmalara (Pausas, 1994; Rey Benayas, 1995; Zhao ve ark., 2005; Negiz ve Aygül, 2019; Arslan ve ark., 2019) göre yükselti ile tür çeşitliliği arasında negatif ilişkiler vardır. Bazı araştırmalarda ise pozitif ilişkiler bulunmaktadır (Pausas ve Sáez, 2000 (Pteridophyte zenginliği); Brewer ve ark., 2003 (ağaç tür zenginliği); Özkan, 2006, (odunsu tür çeşitliliği); Negiz ve Kurt, 2017 (odunsu tür çeşitliliği)).

Toprak pH's1 (pH_1, pH_2) ile $\alpha$ indisi arasında $\mathrm{p}=0,001$ önem seviyesinde, kil_1 miktarı ile $\mathrm{p}=0,05$ önem seviyesinde pozitif ilişkiler vardır. Tür çeşitliliğinin en az olduğu alanların toprak reaksiyonu $(\mathrm{pH})$ genellikle $>5,4$ olup kuvvetli asit ve orta asittir (pH: 5,5-6,4). Tür çeşitliliğin yüksek olduğu örnek alanların ve bitki gruplarının yükseltisi daha düşük, toprak reaksiyonu daha yüksek, hafif asidik ve kil miktarı daha yüksektir. Doğu Akdeniz friganalarında yapılan çalışmada tek yıllıklar, geofitler ve yarı çalımsı kamefitlerin tür zenginliği ile toprak pH'sı arasında pozitif ilişkiler bulunmuştur (Chytrý ve ark., 2010). Mera yönetimi olmayan otlaklarda toprak pH'sı 6,1-6,5 arasında iken tür çeşitliliğinin maksimum olduğu, pH'nın düştüğü ve yükseldiği değerlerde tür çeşitliliğinin azaldığı tespit edilmiştir (Grime, 1973). İspanya'nın doğu Pireneler'indeki doğal sarıçam (Pinus sylvestris) ormanı alt florasında yer alan karayosunu ile $\mathrm{pH}$ arasında pozitif ilişkiler bulunmuştur (Pausas, 1994). Orta Kanada'nın arktik kıyı bölgesinde yer alan nehir ekosistemindeki vasküler, liken ve karayosunu toplumlarında pH'nın 6,5 olduğu alanlarda vasküler bitki tür zenginliğinin en yüksek değerde olduğu, pH artışı ile kommunite içindeki liken zenginliğinin azaldığı, $\mathrm{pH}$ ile karayosunu arasında ise önemli bir ilişkinin bulunmadığı belirlenmiştir (Gould ve Walker, 1999). Araştırma alanımızda ise $\mathrm{pH}$ değerleri, diğer toprak değişkenlerinden daha yüksek bir korelasyon göstermiştir.

Bazı çalışmalarda (Aaron ve Ross, 2001; Arslan ve ark., 2019) korelasyon ve regresyon ağacı yöntemi sonuçları çoklu regresyon analizi sonuçlarından daha açıklayıcı çıkmış ve birden fazla çevresel faktörle ilişkiler ve modeller belirlenmiştir. Ancak çalışmamızda örnek alanların $\alpha$ değerlerilerine uygulanan korelasyon analizi ile yükselti, AGO, pH, ve kil_1 etkili faktörler olarak karşımıza çıkmakla birlikte regresyon ağacı analizinde model tek bir değişkenle (AGO) açıklanmaktadır. Çalışmamızda değerlendirmeye AGO alınmadan yapılan regresyon ağac1 modelinde $\mathrm{R}^{2}=0,2029$ 'dur. Bu model de sadece yükselti değişkeniyle açıklanmaktadır.

Diğer çalışmaların aksine Akdağ kütlesinde çoklu regresyon analizinin 6 . modelinin açıklama katsay1s1 $\left(R^{2}=0,487\right)$ daha yüksektir. Nitekim Akdağ, sarıçam orman toplumları haricinde Türkmendağı'nın orman toplumlarıyla benzerlik göstermektedir. Ancak Türkmendağ orman toplumlarının tür çeşitliliğinin modellenmesinde, aşamalı çoklu regresyon analizi sonucuna göre modelin açıklama payı çok düşüktür (Arslan ve ark., 2019). Dolayısıla orman toplumları birbirine benzemekle birlikte farklı alanların tür çeşitliliğini etkileyen çevresel faktörlerin modellenmesi, farklı analizlerle test edilmelidir.

Araştırmamızda yapılan regresyon analizlerine göre en yüksek açıklama payına $\left(\mathrm{R}^{2=} 0,487\right)$ sahip model aşamalı regresyon analizinin 6. modelinde bulunmuştur. Hem tüm vejetasyon tiplerinin hem de sadece orman vejetasyonunu temsil eden örnek alanlar ile çevresel değişkenler arasındaki doğrusal ilişkilerine ait formüller, $\alpha$ değerini $\% 48,7$ doğrulukla açıklamaktadır $(\mathrm{p}>0,05)$. Orman ve çalı vejetasyonunu oluşturan tüm örnek alanlara ait verilerle belirlenen formül;

$\alpha_{\mathrm{T}}=4,318-0,027$ (AGO)-1,359(andezit-dasit)-0,008 (CGO)+0,039(kil_1)-0,001(yükselti)+0,303(çakılt aşı)

ve orman vejetasyonuna giren örnek alanların $\alpha$ değerini $\left(\alpha_{\mathrm{F}}\right)$ belirleyen çevresel değişkenlere ait formül;

$\alpha_{\mathrm{F}}=4,345-0,028(\mathrm{AGO})-0,007(\mathrm{CGO})+0,039\left(\mathrm{Kil} \_1\right)$ -0,001(yükselti)+0,311(çakıltaş1)-1,098(andezit-dasit)

olarak bulunmuştur.

Formüllerin açıklama katsayıları $(\% 48,7)$ birbirine eşittir. Ayrıca değişkenlere ait katsayılar arasında çok az farklılıklar vardır.

Regresyon ağacı modellerine göre tüm örnek alanlara ait $\alpha$ ve çevresel değişkenlere ait regresyon ağacı modelinin açıklama katsayısı $\mathrm{R}^{2}=0,3042$ olup en yüksek açıklama katsayısına sahip model olarak bulunmuştur. Aşamalı çoklu regresyon modelinden daha düşük açıklama payına sahip- 
tir. Regresyon ağacı modeline göre AGO oranının $\% 88,5$ 'ten düşük olduğu yerlerde $\alpha$ indisi 2,2802 değerini almaktadır. Bu indisin en yüksek değeri ise 3,601; en küçük değeri ise 0,338 'dir.

Çalı vejetasyonunu oluşturan 4. Grubun tür çeşitliliği indis değerlerinin düşük olması, diğer türlerin yaşam alanını kısıtlayan ve gelişimine engel oluşturan baskın bir çalı katının bulunması ile açıklanabilir. Ayrıca diğer bitki gruplarının yayılış alanlarında görülen alan heterojenliğinin daha az olmasının bir sonucu da olabilir. Bu nedenle çalı vejetasyonunun (Grup 4) tür çeşitliliği indis değerleri, ağaç kapalılığı \%75'den daha az olan karaçamın ve saçlı meşenin hâkim olduğu bitki gruplarına göre daha düşük çıkmıştır. Aynı şekilde 5. Grubun hậkim türü doğu kayını olup ağaç kapalılığ1 oldukça yüksektir. Gölgeli ormanları oluşturan bu bitki grubunun çalı katında bulunan tür sayısı ve ot katının örtüş oranları çok düşüktür. Dolayısıyla tür çeşitliği de oldukça azdır. Diğer çalişmalarda (Küçük, 1998; Rad ve ark., 2009; Arslan ve ark., 2019) belirtildiği gibi, bu araştırmada da tür çeşitliliği ve zenginliği, gölgeye dayanıklı klimaks türlerin baskın olduğu meşcerelerde tersine bir ilişki göstermiştir.

Pearson korelasyon analizi sonuçlarına göre yükselti ve AGO, $\alpha$ indisi ile negatif ilişki göstermektedir. Bu sonuçlar bitki gruplarının tür çeşitliliği sonuçları ile uyum göstermektedir. Nitekim Akdağ kütlesinde tür çeşitlilik indislerinin düşük olduğu bitki gruplarından 4. Grup en üst yükseltide (19002080) yayılış göstermektedir. Bu çalı toplumunun aşağ1sında genel olarak 1600-1850 (-1900) metrelerde 5. Grup yer almaktadır. Doğu kayınının hâkim olduğu 5. Grubun ortalama ağaç katı kapalılığ1 $\% 90$ civarındadır. Alfa, beta ve gama çeşitlilik indis değerleri yüksek çıkan toplumlar (Grup 2, Grup 3 ve Grup 1) geniş yayılış alanlarına sahip olduklarından, alan heterojenliği fazladır. Bu gruplarda ağaç katı örtme oranları genellikle $\% 75$ 'den daha azdır. Genel olarak yükseltisi 1100-1550 metreler arasındadır. Yapılan çalışmalara göre tür çeşitliliğinin, alan heterojenliği ve bitki toplumları arasındaki heterojenite farklılığı ile arttığı sonucuna ulaşılmıştır (Pausas, 1994; Gimaret-Carpentier ve ark., 1998; Gould ve Walker, 1999; Pausas ve ark. , 2003; McMaster, 2005; Özçelik ve Gül, 2005; Sfenthourakis ve Panitsa, 2012; Arslan ve ark., 2019). Çalışmamız bulguları, alan ve bitki toplumlarındaki heterojenitenin tür çeşitliliği ve zenginliğini artırdığı sonucunu desteklemektedir.

Yetişme ortamı ve bitki toplumlarının (gruplarının) heterojenliği tür çeşitliliğini arttırmaktadır. Bu nedenle tür çeşitliliğince yüksek alanların belirlenmesi aşamasında, alan heterojenliğinin ve farklı bitki toplumunun geçiş alanlarının olmasına, varsa korunması gerekli hedef türlerin de aynı alan içinde değerlendirilmesine dikkat edilmelidir.

Bitki tür çeşitliliğine yönelik çalışmalardan elde edilen veriler, bitki tür çeşitliliğin model haritalarının oluşturulmasında, fonksiyonel çeşitliliğin ve nadirlik indeksinin belirlenmesinde kullanılabilir. Oluşturulacak veri tabanlı haritalar, yönetilen ormanlarda yapılan müdahaleler ve çevresel etmenler sonucunda bitki tür çeşitliliğindeki değişimin izlenmesine olanak sağlayacaktır.

\section{Kaynaklar}

Aaron, M., Ross K.M. 2001. Environmental factors influencing spatial patterns of shrub diversity in chaparral, Santa Ynez Mountains, California. Journal of Vegetation Science, 12: 41-52.

Açar, M., Satı1, F. 2014. Flora of Akdag (Balikesir, Dursunbey/Turkey). Biological Diversity and Conservation, 7(2): 38-56.

Aertsen, W., Kint, V., Van Orshoven, J., Özkan, K., Muys, B. 2010. Comparison and ranking of different modelling techniques for prediction of site index in Mediterranean mountain forests. Ecological modelling, 221(8): 1119-1130.

Akman, Y. 1999. İklim ve Biyoiklim (Biyoiklim Metodları ve Türkiye İklimleri). Kariyer Matbaacılık, Ankara, $350 \mathrm{~s}$.

Akman, Y., Daget, P.H. 1971. Quelques aspects synoptiques des climats de la Turquie. Bulletin de la Soc. Long. De geographie, 5(3) : 269-300.

Arslan, M., Gülsoy, S., Karataş, R., Koray, E.Ş., Kaptanoğlu, A.S., Mert, A., Kavgac1, A., Özkan, K. 2019. Relationships among forest vegetation, plant diversity and some environmental factors in Türkmen Mountain (Eskişehir-Kütahya, Turkey). Ormancılık Araştırma Dergisi, 6(2): 128-141.

Avc1, M., 1996. The floristic regions of Turkey and a geographical approach for Anatolian diagonal. Review of the Department of Geography, University of Istanbul, 3: 59-91.

Braun-Blanquet, J. 1932. Plant sociology (Translated: Fuller, D. G. and Conard S. H.). ISBN: 3-87429-208-8, West Germany, 439 p.

Brewer, S.W., Rejmánek, M., Webb, M.A.H., Fine, P.V.A. 2003. Relationships of phytogeography and diversity of tropical tree species with limestone topography in southern Belize. Journal of Biogeography, 30: 1669-1688.

Chao, A., Wang, Y.T., Jost, L. 2013. Entropy and the species accumulation curve: a novel entropy estimator via discovery rates of new species, Methods in Ecology and Evolution, 4(11): 1091-1100. 
Chytrý, M., Danihelka J., Axmanová I., Božková, J., Hettenbergerova, E., Li, C.F., Rozbrojová Z., Sekulová, L., Tichý, L., Vymazalová, M., Zeleny, D. 2010. Floristic diversity of an eastern Mediterranean dwarf shrubland: the importance of soil pH. Journal of Vegetation Science, 21: 1125-1137.

Davis, P.H. 1965-1985. Flora of Turkey and the East Aegean Islands. Edinburgh University Press, Vol: 1,2,3,4,5,6,7,8,9, Edinburgh.

Davis, P.H., Mill, R.R., Tan, K. 1998. Flora of Turkey and the East Aegean Islands (Supplement 1). Edinburgh University Press, Vol: 10, Edinburg.

DTREG Predictive Modeling Software 2014. Phillip H. Sherrod www.dtreg.com Erişim Tarihi: 20.07.2019.

Erinç, S. 1984. Klimatoloji ve Metodları. İ.Ü. Yayın No: 3278, Deniz Bilimleri ve Coğrafya Enst. Yayın No: 2, İstanbul.

Fontaine, M., Aerts, R., Özkan, K., Mert, A., Gülsoy, S., Süel, H., Waelkens, M., Muys, B. 2007. Elevation and exposition rather than soil types determine communities and site suitability in Mediterranean mountain forests of southern Anatolia, Turkey. Forest Ecology and Management, 247:18-25.

Gimaret-Carpentier, C., Pélissier, R., Pascal, J.P., Houllier, F. 1998. Sampling strategies for the assessment of tree species diversity. Journal of Vegetation Science, 9: 161-172.

Grime, J.P. 1973. Competitive exclusion in herbaceous vegetation. Nature, 242: 344-347.

Gould, W.A., Walker, M.D. 1999. Plant communities and landscape diversity along a Canadian Arctic river. Journal of Vegetation Science, 10: 537-548.

Gupta, A., Joshi, S.P., Manhas, R.K. 2008. Multivariate analysis of diversity and composition of weed communities of wheat fields in Doon Valley, India. Tropical Ecology, 49(2): 103-112.

Günal, N., 2013. Türkiye'de İklimin doğal bitki örtüsü üzerindeki etkileri. Acta Turcica Çevrimiçi Tematik Türkoloji Dergisi, Online Thematic Journal of Turkic Studies, 5: 1-22.

Güner, A., Özhatay, N., Ekim, T., Başer, K.H.C. 2000. Flora of Turkey and the East Aegean Islands (Supplement 2). Edinburgh University Press, Volume 11, Edinburg.

Güner, E. D., Duman, H. 2013. The revision of genus Seseli (Umbelliferae) in Turkey. Turkish Journal of Botany, 37(6): 1018-1037.

Hennekens, S.M., Schaminée, J.H. 2001. TURBOVEG, a comprehensive data base management system for vegetation data. Journal of vegetation science, 12(4): 589-591.

Heydari, M., Mahdavi, A. 2009. Pattern of Plant Species Diversity in Related to physiographic factors in Melah Gavan Protected Area, Iran. Asian Journal of Biological
Sciences, 2: 21-28.

Işık, K. 2014. Biyolojik Çeşitlilik.(3. Baskı). ANG Vakfı Yayını, Atölye Omsan Matbaa Sanayi ve Ticaret A.Ş., İstanbul, 224 sayfa.

Kılınç, M. ve Kutbay, H.G. 2004. Bitki Ekolojisi. Palme Yayınc1lık, 432 s., Ankara.

Kroetsch, D., Wang, C. 2008. Particle Size Distribution, in section VI Soil Physical Analysis. Section Ed. By Angers D.A., Larney, F.J., In: Soil Sampling and Methods of Analysis 2. Edition, Ed. By Carter, M.R., Gregorich, E.G., Boca Raton, 1224 p, 713-725.

Küçük, M. 1998. Kürtün (Gümüşhane) Örümcek ormanlarının florası ve saf meşcere tiplerinin floristik kompozisyonu. Doğu Karadeniz Ormancılık Araştırma Enstitüsü Teknik Bülten No: 5, Trabzon, $120 \mathrm{~s}$.

McMaster, R.T. 2005. Factors influencing vascular plant diversity on 22 islands of the coast of Eastern North America. Journal of Biogeography 32, 475-492.

McKenney, D.W., Pedlar, J.H. 2003. Spatial Models of Site index based on climate and soil properties for two boreal tree species in Ontario, Canada. Forest Ecology and management, 175: 497-507.

McCune, B., Mefford, M.J. 2006. PC-ORD. Multivariate analysis of Ecological Data, Version 5. MjM Software Design, Gleneden Beach, Oregon. 300 p.

Moisen, G.G., Frescino, T.S. 2002. Comparing five modelling techniques for predicting forest characteristics. Ecological Modelling, 157: 209-225.

Negiz, M.G., Kurt, E.Ö. 2017. Orman yetişme ortamında alfa tür çeşitliliğinin hesaplanması ve çevresel değişkenlerle ilişkileri. Süleyman Demirel Üniversitesi Fen Bilimleri Enstitüsü Dergisi, 21: 93-98.

Negiz, M.G., Aygül, T.İ. 2019. Kurucuova Yöresi'nde odunsu tür zenginliğinin yetişme ortamı faktörlerine göre dağılımı. Turkish Journal of Forestry / Türkiye Ormancılık Dergisi, 20(2): 123-132.

Özbek, M.U. 2010. Türkiye'nin Cota J.Gay (Asteraceae) Cinsinin Taksonomik Revizyonu. Gazi Üniversitesi, Fen Bilimleri Enstitüsü, Biyoloji Anabilim Dalı, Doktora Tezi, $261 \mathrm{~s}$.

Özbek, M.U., Vural, M., Daşkın, R. 2011. A new species of the genus Cota (Asteraceae) from Uludağ, Turkey. Turkish Journal of Botany, 35(4): 331-336.

Özçelik, R., Gül, A.U. 2005. Orman Ekosistemlerindeki Tür Çeşitliliği ve Çeşitlilik İndeksleri. Korunan Doğal Alanlar Sempozyumu, 8 -10 Eylül, Isparta, Sayfa: 543-551.

Özdamar, K. 2009. Paket Programlar ile İstatistiksel Veri Analizi. 7. Bask1, Kaan Kitabevi, Eskișehir, 609 s.

Özkan, K. 2006. Beyşehir Gölü havzası Çarıksaraylar yetişme ortamı yöreler grubunda fizyografik yetişme ortamı faktörleri ile ağaç ve çalı tür çeşitliliği arasındaki 
ilişkiler analizi, Anadolu Üniversitesi Bilim ve Teknoloji Dergisi, 7: 157-16.

Özkan, K. 2012. Sınıflandırma ve regresyon ağacı tekniği (SRAT) ile ekolojik verinin modellenmesi, SDÜ Orman Fakültesi Dergisi (SDÜ Faculty of Forestry Journal), 13: 1-4.

Özkan, K. 2016. Application of information theory for an entropic gradient of ecological sites, Entropy, 18(10), 340 .

Özyuvac1, N. 1999. Meteroloji ve Klimatoloji. İ.Ü. Yayın No: 4196, Orman Fak. Yayın No: 460, ISBN: 975-404544-5, İstanbul.

Pausas, J.G. 1994. Species richness patterns in the understorey of Pyrenean Pinus sylvestris forest. Journal of Vegetation Science, 5: 517-524.

Pausas, J.G., Carreras, J. 1995. The effect of bedrock type, temperature and moisture on species richness of

Pyrenean Scots pine (Pinus sylvestris L.) forests. Vegetatio, 116: 85- 92.

Pausas, J. G., Sáez, L. 2000. Pteridophyte richness in the NE Iberian Peninsula: biogeographic patterns. Plant ecology, 148(2): 195-205.

Pausas, J.G., Carreras, J., Ferré, A., Font, X. 2003. Coarse-scale plant species richness in relation to environmental heterogeneity. Journal of Vegetation Science, 14: 661-668.

Pimenov, M.G., Kljuykov, E.V. 2010. Two new species of Seseli (Umbelliferae) from Turkey. Flora Mediterranea, 20: 19-27.

Poulos, H.M., Taylor, A.H., Beaty, R.M. 2007. Environmental controls on dominance and diversity of woody plant species in a Madrean, Sky Island ecosystem, Arizona, USA. Plant Ecology, 193: 15-30.

Rad, J.E., Manthey, M., Mataji, A. 2009. Comprasion of plant species diversity with different plant communities in decidious forests. International Journal of Environmental Science \& Technology, 6(3): 389-394.

Rey-Benayas, J.M. 1995. Patterns of diversity in the stra- ta of boreal montane forest in British Columbia. Journal of Vegetation Science, 6: 95-98.

Sfenthourakis, S., Panitsa M. 2012. From plots to islands: species diversity at different scales. Journal of Biogeography, 39: 750-759.

Shannon, C.E. 1948. A mathematical theory of communication. The Bell System Technical Journal, 27: 379-423

Sönmez, S., Boyraz, N. 2003. Akdağın Orman Ekosistemi, Alaçam Dağları ve Dursunbey I. Ulusal Sempozyumu 2002, Bildiriler Kitab1, İstanbul, 115-120.

Tichy, L. 2002. JUICE, software for vegetation classification. Journal of Vegetation Science 13: 451 - 453.

TSE 1990. Modifiye Walkley - Black yöntemi Organik Madde Analizi TS 8336

TSE 1996a. Elektriksel Öz iletkenlik Tayini TS ISO 11265.

TSE 1996b. Karbonat Muhtevası Tayini - Volumetrik Metot TS 8335 ISO 10693.

TSE 2013. pH analizi ISO 10390. Türk Standartları Enstitüsü.

Tunçkol, B., Yaşayacak, H., Aksoy, N. 2015. Presence of Senecio sylvaticus L.(Asteraceae) in Turkey. Biodiversity Research and Conservation, 39: 33-36.

Tutin, T.G., Heywood, V.H. 2010. Flora Europaea, Plantaginaceae to Compositae (and Rubiaceae). Volume 4, Sixt printing 2006, Cambridge University Press, p 505.

Urban, D.L., Miller, C., Halpin, P.N., Stephenson, N.L. 2000. Forest pattern in Sierran landscapes: the physical template. Landscape Ecol, 15: 603-620.

Yaltırık, F., Efe, A. 1996. Otsu Bitkiler Sistematiği. II. Bask1, İstanbul Üniversitesi Yayın No: 3940, Orman fakültesi yayın No: 10, 518 s., İ.Ü. Basımevi ve Film Merkezi, İstanbul.

Zhao, C.M., Chen, W.L., Tian, Z.Q., Xie, Z.Q. 2005. Altitudinal pattern of plant species diversity in Shennongjia Mountains, Central China. Journal of Integrative Plant Biology, 47(12): 1431-1449 
EK-1. Örnek alanların takson sayıları, $\alpha$ çeşitlilik indisi değerleri ve dâhil oldukları bitki grupları Appendix-1: Taxa numbers, $\alpha$ diversity index values and plant groups of the sample areas

\begin{tabular}{|c|c|c|c|c|c|c|c|c|c|c|c|}
\hline B_G & $\begin{array}{c}\text { Ör } \\
\text { A }\end{array}$ & $\begin{array}{c}\text { Takson } \\
\text { S }\end{array}$ & $\alpha$ & B_G & $\begin{array}{c}\text { Ör } \\
\text { A }\end{array}$ & $\begin{array}{c}\text { Takson } \\
\text { S }\end{array}$ & $\alpha$ & B_G & $\begin{array}{c}\text { Ör } \\
\text { A }\end{array}$ & $\begin{array}{c}\text { Takson } \\
\text { S }\end{array}$ & $\alpha$ \\
\hline 3 & 70 & 67 & 3,601 & 3 & 73 & 35 & 2,422 & 3 & 85 & 19 & 1,914 \\
\hline 3 & 83 & 62 & 3,396 & 3 & 107 & 28 & 2,410 & 5 & 40 & 16 & 1,895 \\
\hline 3 & 101 & 60 & 3,324 & 3 & 34 & 27 & 2,409 & 3 & 54 & 23 & 1,871 \\
\hline 2 & 113 & 56 & 3,274 & 3 & 121 & 29 & 2,408 & 1 & 1 & 18 & 1,860 \\
\hline 3 & 93 & 56 & 3,221 & 3 & 86 & 34 & 2,407 & 4 & 3 & 20 & 1,858 \\
\hline 1 & 68 & 51 & 3,150 & 3 & 104 & 36 & 2,404 & 3 & 30 & 23 & 1,844 \\
\hline 3 & 106 & 53 & 3,139 & 3 & 94 & 27 & 2,388 & 1 & 28 & 20 & 1,831 \\
\hline 3 & 123 & 38 & 3,045 & 3 & 10 & 38 & 2,376 & 4 & 5 & 24 & 1,822 \\
\hline 3 & 56 & 42 & 3,034 & 3 & 24 & 28 & 2,373 & 3 & 55 & 19 & 1,816 \\
\hline 3 & 60 & 46 & 2,985 & 3 & 21 & 27 & 2,355 & 4 & 7 & 22 & 1,812 \\
\hline 1 & 36 & 43 & 2,976 & 1 & 105 & 28 & 2,355 & 5 & 84 & 22 & 1,717 \\
\hline 3 & 124 & 44 & 2,963 & 1 & 37 & 26 & 2,326 & 1 & 32 & 22 & 1,683 \\
\hline 2 & 49 & 44 & 2,939 & 3 & 110 & 36 & 2,325 & 5 & 11 & 16 & 1,675 \\
\hline 3 & 71 & 45 & 2,936 & 3 & 88 & 27 & 2,309 & 3 & 43 & 20 & 1,675 \\
\hline 3 & 4 & 38 & 2,840 & 3 & 89 & 39 & 2,306 & 1 & 42 & 17 & 1,640 \\
\hline 3 & 90 & 48 & 2,794 & 3 & 98 & 24 & 2,299 & 1 & 57 & 15 & 1,630 \\
\hline 3 & 58 & 35 & 2,777 & 3 & 127 & 37 & 2,283 & 1 & 47 & 20 & 1,540 \\
\hline 3 & 62 & 35 & 2,777 & 1 & 45 & 24 & 2,268 & 3 & 20 & 16 & 1,519 \\
\hline 3 & 97 & 40 & 2,731 & 3 & 46 & 26 & 2,263 & 5 & 76 & 13 & 1,484 \\
\hline 3 & 82 & 32 & 2,683 & 3 & 91 & 26 & 2,238 & 1 & 52 & 14 & 1,476 \\
\hline 3 & 26 & 40 & 2,673 & 4 & 6 & 25 & 2,235 & 5 & 61 & 15 & 1,452 \\
\hline 3 & 95 & 34 & 2,672 & 1 & 111 & 26 & 2,226 & 5 & 19 & 13 & 1,437 \\
\hline 3 & 69 & 36 & 2,665 & 3 & 78 & 34 & 2,223 & 1 & 22 & 13 & 1,389 \\
\hline 3 & 102 & 40 & 2,660 & 3 & 75 & 32 & 2,213 & 1 & 115 & 12 & 1,327 \\
\hline 3 & 100 & 40 & 2,654 & 3 & 14 & 25 & 2,211 & 5 & 114 & 12 & 1,320 \\
\hline 3 & 25 & 28 & 2,633 & 3 & 80 & 33 & 2,164 & 1 & 112 & 14 & 1,309 \\
\hline 3 & 13 & 33 & 2,624 & 2 & 66 & 29 & 2,146 & 5 & 59 & 17 & 1,286 \\
\hline 2 & 33 & 37 & 2,618 & 3 & 118 & 23 & 2,144 & 1 & 2 & 10 & 1,268 \\
\hline 3 & 48 & 34 & 2,615 & 1 & 126 & 34 & 2,137 & 1 & 35 & 10 & 1,204 \\
\hline 1 & 67 & 34 & 2,577 & 3 & 31 & 29 & 2,132 & 5 & 18 & 15 & 1,166 \\
\hline 1 & 119 & 30 & 2,566 & 1 & 65 & 27 & 2,108 & 1 & 103 & 15 & 1,154 \\
\hline 3 & 99 & 30 & 2,543 & 3 & 74 & 23 & 2,107 & 5 & 117 & 9 & 1,093 \\
\hline 3 & 122 & 31 & 2,542 & 3 & 108 & 22 & 2,088 & 3 & 44 & 7 & 1,081 \\
\hline 3 & 29 & 41 & 2,512 & 3 & 12 & 22 & 2,083 & 5 & 116 & 9 & 1,013 \\
\hline 2 & 51 & 38 & 2,509 & 3 & 87 & 27 & 2,071 & 5 & 38 & 13 & 0,996 \\
\hline 3 & 63 & 30 & 2,478 & 1 & 50 & 28 & 2,044 & 5 & 96 & 9 & 0,847 \\
\hline 3 & 17 & 29 & 2,467 & 3 & 79 & 28 & 2,037 & 5 & 39 & 7 & 0,699 \\
\hline 3 & 77 & 28 & 2,466 & 3 & 16 & 20 & 2,030 & 5 & 81 & 8 & 0,634 \\
\hline 3 & 92 & 35 & 2,452 & 3 & 41 & 27 & 2,026 & 5 & 9 & 7 & 0,547 \\
\hline 3 & 120 & 32 & 2,440 & 3 & 15 & 23 & 2,020 & 5 & 8 & 7 & 0,496 \\
\hline 3 & 109 & 31 & 2,430 & 3 & 23 & 27 & 2,009 & 5 & 53 & 6 & 0,338 \\
\hline 3 & 64 & 33 & 2,424 & 3 & 27 & 25 & 1,995 & & & & \\
\hline 3 & 72 & 41 & 2,423 & 3 & 125 & 26 & 1,982 & & & & \\
\hline
\end{tabular}

Ör_A: Örnek alan, B_G: Bitki grubu; Takson_S: Takson sayısı 
Ek-2. Tür çeșitliliği ile ilișkili olan çevresel faktörler

Appendix-2. Environmental factors associated with species diversity

Ö_A B_G Kil_1 pH_1 pH_2 AGO ÇGO Dasit- Ç_taşı Yük. Ö_A B_G Kil_1 pH_1 pH_2 AGO ÇGO Dasit- Ç_taşı Yük.

\begin{tabular}{|c|c|c|c|c|c|c|c|c|c|c|c|c|c|c|c|c|c|c|c|}
\hline \multicolumn{15}{|c|}{ Prok. } & \multicolumn{5}{|c|}{ Prok. } \\
\hline 1 & 1 & 8,09 & 6,92 & 6,23 & 60 & 8 & 0 & 0 & 1269 & 72 & 3 & 24,61 & 5,89 & 5,75 & 60 & 1,2 & 0 & 0 & 1500 \\
\hline 2 & 1 & 4,10 & 6,21 & 5,92 & 60 & 20 & 0 & 0 & 1446 & 73 & 3 & 25,49 & 5,77 & 5,65 & 55 & 43 & 0 & 0 & 1553 \\
\hline 22 & 1 & 10,16 & 5,41 & 5,00 & 75 & 1 & 0 & 0 & 1350 & 74 & 3 & 22,27 & 5,86 & 5,58 & 70 & 4 & 0 & 0 & 1605 \\
\hline 28 & 1 & 22,48 & 6,15 & 6,22 & 70 & 1 & 0 & 0 & 1423 & 75 & 3 & 24,55 & 5,85 & 5,79 & 93 & 20 & 0 & 0 & 1617 \\
\hline 32 & 1 & 20,85 & 6,32 & 6,41 & 83 & 3 & 0 & 0 & 1335 & 77 & 3 & 16,83 & 5,45 & 5,52 & 75 & 4 & 0 & 0 & 1550 \\
\hline 35 & 1 & 10,04 & 6,16 & 5,96 & 70 & 30 & 0 & 0 & 1125 & 78 & 3 & 14,30 & 5,72 & 5,67 & 85 & 5 & 0 & 0 & 1490 \\
\hline 36 & 1 & 10,12 & 5,85 & 6,01 & 45 & 50 & 0 & 0 & 1133 & 79 & 3 & 18,80 & 5,48 & 5,42 & 90 & 0,3 & 0 & 0 & 1570 \\
\hline 37 & 1 & 10,07 & 6,27 & 6,06 & 50 & 40 & 0 & 0 & 1216 & 80 & 3 & 27,20 & 5,69 & 5,72 & 85 & 1 & 0 & 0 & 1578 \\
\hline 42 & 1 & 16,30 & 5,59 & 5,38 & 85 & 40 & 0 & 0 & 1536 & 82 & 3 & 18,44 & 4,99 & 5,11 & 60 & 12 & 0 & 0 & 1660 \\
\hline 45 & 1 & 14,32 & 6,12 & 6,20 & 70 & 15 & 0 & 0 & 1435 & 83 & 3 & 22,72 & 5,79 & 5,61 & 65 & 15 & 0 & 0 & 1533 \\
\hline 47 & 1 & 14,45 & 6,29 & 6,58 & 85 & 1 & 0 & 0 & 1323 & 85 & 3 & 18,29 & 6,14 & 5,88 & 75 & 7 & 0 & 0 & 1309 \\
\hline 50 & 1 & 16,18 & 6,60 & 6,85 & 67 & 57 & 0 & 0 & 1029 & 86 & 3 & 18,41 & 5,45 & 5,48 & 85 & 15 & 0 & 0 & 1500 \\
\hline 52 & 1 & 16,48 & 5,87 & 6,23 & 70 & 5 & 0 & 0 & 1290 & 87 & 3 & 19,06 & 5,79 & 6,28 & 85 & 1 & 0 & 0 & 1405 \\
\hline 57 & 1 & 12,46 & 6,02 & 6,58 & 63 & 60 & 0 & 0 & 1312 & 88 & 3 & 16,92 & 5,43 & 5,39 & 80 & 5 & 0 & 0 & 1461 \\
\hline 65 & 1 & 16,24 & 6,29 & 6,52 & 60 & 40 & 0 & 0 & 1113 & 89 & 3 & 22,97 & 5,79 & 5,80 & 80 & 2,5 & 0 & 0 & 1428 \\
\hline 67 & 1 & 14,28 & 6,93 & 6,42 & 68 & 15 & 0 & 0 & 1092 & 90 & 3 & 19,70 & 5,57 & 5,93 & 80 & 0,3 & 0 & 0 & 1626 \\
\hline 68 & 1 & 18,75 & 6,55 & 5,58 & 45 & 60 & 0 & 0 & 1208 & 91 & 3 & 16,72 & 5,76 & 5,91 & 65 & 7 & 0 & 0 & 1258 \\
\hline 103 & 1 & 12,25 & 6,20 & 5,87 & 77 & 0,3 & 0 & 1 & 1382 & 92 & 3 & 28,76 & 5,73 & 5,63 & 65 & 2 & 0 & 0 & 1239 \\
\hline 105 & 1 & 19,78 & 5,55 & 5,99 & 65 & 50 & 0 & 0 & 1304 & 93 & 3 & 25,02 & 5,81 & 5,69 & 63 & 3 & 0 & 0 & 1188 \\
\hline 111 & 1 & 12,22 & 6,33 & 6,12 & 60 & 15 & 0 & 0 & 1332 & 94 & 3 & 20,58 & 5,50 & 5,51 & 70 & 4 & 0 & 0 & 1326 \\
\hline 112 & 1 & 10,19 & 5,95 & 5,81 & 75 & 6 & 0 & 0 & 1275 & 95 & 3 & 12,30 & 5,69 & 5,45 & 60 & 13 & 0 & 1 & 1238 \\
\hline 115 & 1 & 20,13 & 6,14 & 5,70 & 67 & 7 & 0 & 0 & 990 & 97 & 3 & 18,88 & 6,25 & 6,22 & 90 & 3 & 0 & 1 & 1445 \\
\hline 119 & 1 & 20,44 & 6,47 & 6,54 & 75 & 12 & 0 & 1 & 1115 & 98 & 3 & 12,47 & 5,94 & 5,79 & 50 & 65 & 0 & 1 & 1310 \\
\hline 126 & 1 & 24,62 & 6,07 & 5,91 & 77 & 55 & 0 & 0 & 1250 & 99 & 3 & 14,60 & 6,13 & 5,93 & 75 & 2 & 0 & 1 & 1280 \\
\hline 33 & 2 & 22,39 & 6,25 & 6,30 & 75 & 50 & 0 & 0 & 1240 & 100 & 3 & 16,93 & 6,13 & 6,05 & 85 & 30 & 0 & 1 & 1213 \\
\hline 49 & 2 & 16,40 & 6,06 & 5,73 & 60 & 10 & 0 & 0 & 1084 & 101 & 3 & 19,24 & 5,82 & 5,56 & 75 & 18 & 0 & 1 & 1445 \\
\hline 51 & 2 & 20,56 & 6,37 & 5,38 & 73 & 7 & 0 & 0 & 1135 & 102 & 3 & 23,50 & 6,46 & 6,35 & 80 & 10 & 0 & 1 & 1370 \\
\hline 66 & 2 & 18,21 & 6,84 & 6,70 & 80 & 14 & 0 & 0 & 756 & 104 & 3 & 12,51 & 5,91 & 6,11 & 85 & 3 & 0 & 1 & 1292 \\
\hline 113 & 2 & 30,67 & 6,29 & 6,08 & 45 & 60 & 0 & 0 & 1373 & 106 & 3 & 21,18 & 6,33 & 6,08 & 87 & 12 & 0 & 0 & 1354 \\
\hline 4 & 3 & 14,71 & 5,10 & 5,82 & 73 & 4 & 0 & 0 & 1374 & 107 & 3 & 19,76 & 6,23 & 5,86 & 74 & 10 & 0 & 1 & 1230 \\
\hline 10 & 3 & 28,87 & 6,26 & 6,11 & 35 & 93 & 0 & 0 & 1647 & 108 & 3 & 16,35 & 5,91 & 5,67 & 90 & 1 & 0 & 1 & 1293 \\
\hline 12 & 3 & 16,36 & 6,26 & 6,10 & 65 & 2 & 0 & 0 & 1615 & 109 & 3 & 26,61 & 5,58 & 5,43 & 80 & 10 & 0 & 0 & 1362 \\
\hline 13 & 3 & 24,92 & 6,15 & 5,96 & 70 & 10 & 0 & 0 & 1697 & 110 & 3 & 14,82 & 5,93 & 5,59 & 85 & 0,5 & 0 & 0 & 1576 \\
\hline 14 & 3 & 18,52 & 6,14 & 6,37 & 65 & 38 & 0 & 0 & 1612 & 118 & 3 & 20,47 & 5,78 & 6,16 & 70 & 6 & 0 & 0 & 1300 \\
\hline 15 & 3 & 23,32 & 5,72 & 6,17 & 58 & 60 & 0 & 0 & 1537 & 120 & 3 & 18,50 & 6,74 & 6,28 & 68 & 7 & 0 & 1 & 1265 \\
\hline 16 & 3 & 22,87 & 6,12 & 5,91 & 70 & 30 & 0 & 0 & 1656 & 121 & 3 & 18,41 & 6,67 & 6,57 & 65 & 25 & 0 & 1 & 1254 \\
\hline 17 & 3 & 23,15 & 5,67 & 5,41 & 60 & 3 & 0 & 0 & 1710 & 122 & 3 & 16,40 & 6,02 & 5,74 & 60 & 5 & 0 & 0 & 1387 \\
\hline 20 & 3 & 18,78 & 5,25 & 5,13 & 85 & 2 & 0 & 0 & 1446 & 123 & 3 & 22,47 & 5,98 & 6,07 & 45 & 50 & 0 & 0 & 1373 \\
\hline 21 & 3 & 18,62 & 5,31 & 5,46 & 70 & 0,03 & 0 & 1 & 1573 & 124 & 3 & 28,93 & 6,23 & 5,94 & 80 & 10 & 0 & 0 & 1352 \\
\hline 23 & 3 & 16,14 & 5,20 & 5,05 & 83 & 0,1 & 0 & 1 & 1499 & 125 & 3 & 16,28 & 6,36 & 6,35 & 80 & 4 & 0 & 0 & 1253 \\
\hline 24 & 3 & 22,67 & 5,52 & 5,58 & 75 & 5 & 0 & 0 & 1602 & 127 & 3 & 24,70 & 5,61 & 5,64 & 80 & 0,3 & 0 & 1 & 1276 \\
\hline 25 & 3 & 20,96 & 5,70 & 5,45 & 75 & 20 & 0 & 1 & 1531 & 3 & 4 & 18,45 & 5,55 & 5,84 & 0 & 85 & 1 & 0 & 1906 \\
\hline 26 & 3 & 24,07 & 5,40 & 6,85 & 55 & 0,01 & 0 & 0 & 1436 & 5 & 4 & 22,85 & 5,56 & 5,60 & 0 & 85 & 1 & 0 & 1990 \\
\hline 27 & 3 & 16,46 & 6,61 & 6,31 & 85 & 2 & 0 & 0 & 1300 & 6 & 4 & 27,15 & 5,32 & 5,25 & 0 & 70 & 1 & 0 & 2042 \\
\hline 29 & 3 & 24,79 & 6,43 & 6,24 & 75 & 2 & 0 & 0 & 1520 & 7 & 4 & 27,03 & 6,00 & 5,75 & 0 & 95 & 1 & 0 & 2024 \\
\hline 30 & 3 & 18,39 & 6,13 & 6,35 & 80 & 1 & 0 & 0 & 1356 & 8 & 5 & 22,56 & 5,62 & 5,11 & 90 & 3 & 1 & 0 & 1849 \\
\hline 31 & 3 & 26,75 & 6,38 & 6,17 & 80 & 18 & 0 & 0 & 1409 & 9 & 5 & 20,60 & 4,94 & 5,57 & 95 & 10 & 0 & 0 & 1765 \\
\hline 34 & 3 & 21,31 & 6,32 & 5,80 & 70 & 4 & 0 & 0 & 1425 & 11 & 5 & 20,86 & 6,10 & 6,11 & 80 & 5 & 0 & 0 & 1674 \\
\hline 41 & 3 & 8,36 & 5,27 & 5,61 & 85 & 5 & 0 & 0 & 1639 & 18 & 5 & 20,75 & 5,18 & 4,76 & 97 & 8 & 0 & 0 & 1659 \\
\hline 43 & 3 & 18,66 & 6,03 & 6,39 & 83 & 4 & 0 & 0 & 1420 & 19 & 5 & 14,55 & 5,36 & 4,97 & 90 & 30 & 0 & 1 & 1557 \\
\hline 44 & 3 & 16,42 & 6,12 & 5,63 & 60 & 6 & 0 & 0 & 1518 & 38 & 5 & 16,39 & 5,16 & 4,81 & 98 & 20 & 0 & 0 & 1842 \\
\hline 46 & 3 & 18,56 & 6,14 & 6,21 & 75 & 0,5 & 0 & 0 & 1388 & 39 & 5 & 18,50 & 5,13 & 4,79 & 95 & 35 & 0 & 0 & 1839 \\
\hline 48 & 3 & 16,46 & 6,25 & 6,38 & 70 & 7 & 0 & 0 & 1286 & 40 & 5 & 16,57 & 5,40 & 5,34 & 80 & 20 & 0 & 0 & 1762 \\
\hline 54 & 3 & 27,12 & 6,29 & 6,02 & 75 & 0,8 & 0 & 0 & 1598 & 53 & 5 & 16,62 & 6,55 & 6,20 & 95 & 77 & 0 & 0 & 1717 \\
\hline 55 & 3 & 20,68 & 6,12 & 6,57 & 43 & 57 & 0 & 0 & 1515 & 59 & 5 & 24,81 & 5,43 & 5,50 & 95 & 50 & 0 & 0 & 1611 \\
\hline 56 & 3 & 24,86 & 6,60 & 6,58 & 45 & 6 & 0 & 0 & 1372 & 61 & 5 & 16,63 & 6,16 & 6,14 & 80 & 3 & 0 & 0 & 1425 \\
\hline 58 & 3 & 22,93 & 6,52 & 6,21 & 65 & 5 & 0 & 0 & 1429 & 76 & 5 & 22,77 & 5,55 & 4,89 & 65 & 8 & 0 & 0 & 1815 \\
\hline 60 & 3 & 23,33 & 6,29 & 5,79 & 65 & 33 & 0 & 0 & 1481 & 81 & 5 & 22,96 & 5,33 & 4,78 & 90 & 60 & 0 & 0 & 1780 \\
\hline 62 & 3 & 16,51 & 6,14 & 6,46 & 70 & 3 & 0 & 0 & 1291 & 84 & 5 & 26,56 & 5,84 & 5,59 & 90 & 3 & 0 & 0 & 1340 \\
\hline 63 & 3 & 12,41 & 6,17 & 5,98 & 65 & 0,3 & 0 & 0 & 1210 & 96 & 5 & 20,62 & 5,36 & 5,32 & 97 & 5 & 0 & 1 & 1456 \\
\hline 64 & 3 & 14,50 & 5,75 & 5,87 & 63 & 0,5 & 0 & 0 & 1194 & 114 & 5 & 22,92 & 6,28 & 5,96 & 95 & 0,5 & 0 & 0 & 1458 \\
\hline 69 & 3 & 16,53 & 6,23 & 6,44 & 70 & 1 & 0 & 0 & 1280 & 116 & 5 & 21,31 & 5,14 & 5,90 & 95 & 0,5 & 0 & 0 & 1396 \\
\hline 70 & 3 & 29,97 & 5,71 & 5,74 & 40 & 35 & 0 & 0 & 1528 & 117 & 5 & 27,36 & 5,67 & 5,59 & 97 & 1 & 0 & 0 & 1350 \\
\hline 71 & 3 & 22,61 & 5,29 & 5,49 & 50 & 20 & 0 & 0 & 1482 & & & & & & & & & & \\
\hline
\end{tabular}

Ör_A: Örnek alan; B_G: Bitki grubu; AGO: Ağaç katı genel örtme oranı; ÇGO: Çalı katı genel örtme oranı; And.: Andezit; Prok.: Proklastik; Ç_taşı: Çakıltaşı 